\title{
Inside-of-Africa: How landscape openness shaped Homo sapiens evolution by facilitating dispersal and gene-flow in Middle and Late Pleistocene Africa
}

\author{
Mick N.T. Bönnen, William D. Gosling \& Henry Hooghiemstra \\ Institute for Biodiversity and Ecosystems Dynamics, University of Amsterdam, \\ Amsterdam, The Netherlands
}

\begin{abstract}
Homo sapiens as a clade originated c. 500 thousand years before present $(500 \mathrm{ka})$ as it diverged from Homo neanderthalensis. The topic of early H. sapiens evolution and dispersal since this cladogenesis has long been of interest in scientific literature and public debate. The development of this field has been significantly accelerated in recent years by the advances made in the scientific fields of archaeological, anthropological and genetic research; exemplified by the publication of the earliest observed fossil belonging to the archaic $H$. sapiens clade at Jebel Irhoud, Morocco, dated at c. $315 \mathrm{ka}$ in 2017. Recent evidence from these fields opposes the long-held view that anatomically modern humans (AMH) evolved linearly from a single population. Instead, a pan-African model of evolution is proposed, whereby geographically isolated $H$. sapiens populations, possibly shaped and maintained by ecological boundaries, evolved independently with fluctuating degrees of gene-flow over time. A thorough understanding of the ecological context these hominins experienced has long been hampered by spatial and temporal gaps in the African palaeovegetation record. Records of past vegetation that cover timescales relevant to the emergence of AMHs now exist that are relevant to environmental change in northen, southern, eastern, western and central Africa. This means it is becoming possible to explore how hominin evolutionary development coincided with the changing vegetational (habitat) context. We present the idea of a three-stage 'Inside-of-Africa' environmental framework for hominin evolution: (i) a predominance of hospitable vegetation 500-400 ka facilitating initial dispersal of archaic H. sapiens, (ii) a predominance of ecological barriers (e.g. deserts and rainforests) 400-250 ka limiting dispersal and gene-flow, causing independent evolution, and (iii) a predominance of hospitable vegetation 250-100 ka (re-)connecting populations and resulting in the combination of the full suite of contemporary AMH characteristics. To test this framework we review and synthesize all available long (>c. $100 \mathrm{ka}$ ) lacustrine palynological records relevant to past vegetation change across Africa. We find the past vegetation data supports the waxing and waning of hospitable vegetation and ecological barriers during the last $500 \mathrm{ka}$ in line with the timings proposed in our environmental framework.
\end{abstract}




\subsection{INTRODUCTION}

\subsubsection{Archaic Homo sapiens}

Africa is regarded as the cradle of our own species (Mounier and Mirazón Lahr 2016) because it is where the archaic Homo sapiens clade diverged from the H. heidelbergensis c. 700-400 thousands of years before present (ka) (Stringer 2016), and where we shared our last common ancestor with $H$. neanderthalensis c. 440-410 ka (Endicott et al. 2010) (Figure 1). Although the exact location of cladogenesis remains unknown, these archaic forms of $H$. sapiens radiated all over Africa. Currently, the earliest 'archaic' manifestations of the H. sapiens clade are found in Jebel Irhoud, Morocco, comprising of cranial fossils dated to be about $315 \mathrm{ka}$ (Hublin et al. 2017; Richter et al. 2017). Later dated archaic H. sapiens remains include fossils from Florisbad in South Africa (c. $260 \mathrm{ka}$ ) (Grun et al. 1996) and Omo Kibish and Herto, both Ethiopia, which have estimated ages of c. 195 and c. 160 ka respectively (McDougall et al. 2005; White et al. 2003). Even though all these archaic humans belong to the $H$. sapiens clade, and share a fairly recent last common ancestor, their fossilized remains show distinct spatial and temporal morphological variation when compared with each other, and with anatomically modern humans (AMH; Gunz et al. 2009).

The pan-African spread of hominins, in conjunction with the array of morphological variation (Hammond et al. 2017; Lieberman et al. 2002; Neubauer et al. 2018; Pearson 2008), has lead the modern scientific discourse to consider a mosaic-like pattern for the evolution of modern human traits (Gunz et al. 2009; Scerri et al., 2017a; Stringer 2016). A mosaic-like pan-African pattern could have been created if populations became (semi-)isolated for millennia by distance and/or ecological barriers (such as deserts or dense rainforests). The consequence could be that specific modern human traits might have evolved independently in different regions and became combined later when populations reconnected. The amalgamation of our modern characteristics could have therefore potentially been strongly mediated by past environmental changes. For example, periods of increased landscape connectivity between hominin populations, brought about by an increasing predominance of open vegetation, could have facilitated gene flow between small semi-isolated populations across Africa (Bertola et al. 2016). Recent genetic studies have suggested that between c. 250-100 ka most extant lineages emerged (Lipson et al. 2020). The eventual admixture of individual traits associated with these populations led to the homogenization of the human phenotype, thereby refuting the notion that our lineage can be traced back to one specific region, but favouring a pan-African view of $H$. sapiens evolution instead. Analyses of whole-genome sequences of contemporary African populations provide a time-dependent estimate of gene flow that suggests a pattern of population separation, followed by isolation, and then subsequent recombination (Wang et al. 2020).

Similar to morphological characteristics, spatiotemporal diversifications since our last common ancestor with $H$. neanderthalensis are also reflected in behavioural practices such as material cultures. An abandonment of large and crude cutting tools (e.g. hand axes) in favour of more sophisticated techniques for tool-carving ('prepared-core' technologies) occurred almost simultaneously on a pan-African scale. These innovations in stone tool technology followed a long period of stasis (the Early Stone Age [ESA] c. $3 \mathrm{Myr}$ to $200 \mathrm{kyr}$ BP) and mark the start of the Middle Stone Age (MSA) period (c. 280-20 kyr BP, Galway-Witham et al. 2019). The MSA is also when regionally distinctive material cultures involving complex stone tools first become apparent in the archaeological records. For example during the MSA features such as tangled implements (securing stone tools into wooden hafts) emerged in northern African populations (Scerri 2017b), central African materialistic culture started to be characterized by distinctive 


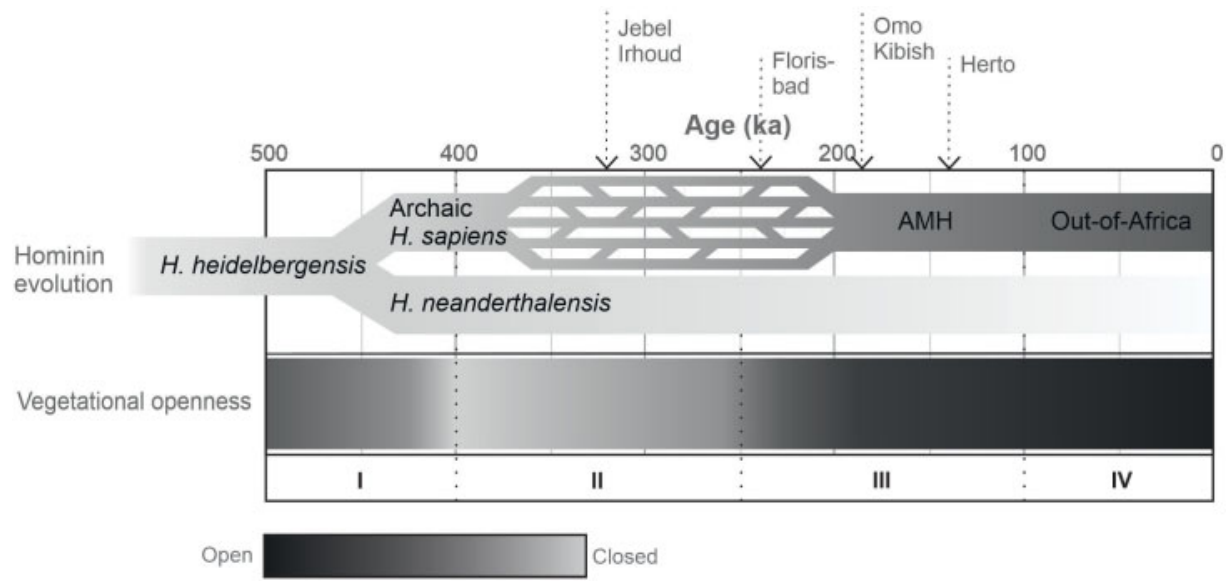

Figure 1. 'Inside-of-Africa' conceptual environmental framework related to the evolution and development of hominins. Vegetation openness relates to the proportion of open (savannah) or closed (forest) vegetation on the continent. General characteristics of vegetation for each period are indicated by (I) open and hospitable to hominins, (II) closed with more environmental barriers to hominins, and (III) open and hospitable for hominins. AMH $=$ Anatomically Modern Humans. Out-of-Africa = the period of human dispersal from the African continent (IV). Key archaeological sites yielding H. sapiens fossils indicated are Jebel Irhoud, Morocco (Hublin et al. 2017), Florisbad, South Africa (Grun et al. 1996), Omo Kibish, Ethiopia (McDougall et al. 2005), and Herto, Ethiopia (White et al. 2003).

stone tools (Scerri 2017a), while southern African cultural artifacts started to include complex material aspects; such as the use of ochre, bone tools and shell beads (D'Errico et al. 2017).

\subsubsection{Hypothesis development}

In this review, we focus on how changing environments could have shaped hominin evolution inside Africa. Building on the literature, we propose here a new framework for understanding this interplay between archaic $H$. sapiens and their contemporary landscapes. Our 'Inside-of-Africa' framework includes alternating periods of environmental hospitability and ecological barriers that either limit or encourage dispersal (Figure 1):

I. Initial dispersal of archaic H. sapiens across Africa (c. 500-400 ka) was facilitated by increased landscape openness, which made areas generally more hospitable (hereafter defined as landscapes not dominated by dense (rain)forests or deserts, but rather by open ecosystem mosacis, including: (wooded) grasslands, savannahs, and gallery forests).

II. Intraspecific variation was promoted and cultural development fragmented between (c. 400-250 ka) by a rise in the number of environmental barriers (e.g. arid deserts and impenetrable forests), which (semi-)isolated $H$. sapiens populations to environmentally constrained hospitable regions (refugia).

III. The (re-)combination of traits into the full suite of AMH characteristics (c. 250-100 ka) was facilitated by increased landscape openness.

This review collates lacustrine palynological records with a pan-African spatial coverage from the period relevant to hominin evolution as outlined above (Figure 1). These data assess the current state of available information on past vegetation from terrestrial sites. We use the synthesized past vegetation information to test ideas on the evolution, development and dispersal of hominins. Specifically, we classify the long palynological records as indicative of relatively more open, or closed, vegetation structure (grasslands to dense forests) and identify any directional vegetation trends coincident with hominin evolution. 


\subsection{AFRICAN ENVIRONMENTS DURING THE MIDDLE AND UPPER PLEISTOCENE}

\subsubsection{Current ecosystems}

The wide range in topography and climatic conditions across Africa caused varied landscapes that are home to a plethora of ecosystems (Dupont 2011; White 1983). Following Dupont's (2011) simplified version of the African vegetation classifications made by White (1983), we can distinguish between eleven different biomes in contemporary Africa (Figure 2A).

The continent's most northern and south-western extent is typified by arid biomes. Generally speaking, we find Mediterranean forests along the north-African coast from Morocco to Egypt adjoining the Mediterranean Sea, while Africa's most southern tip, the southern-African coasts and Cape Fold Mountains, are dominated by fynbos vegetation. Mediterranean forests have a significant presence of arboreal species; typically oak (Quercus) and maple (Acer) in broadleaved forests, while pine (Pinus) and yew (Taxus) dominate the coniferous forests. The fynbos vegetation on the other hand has a low density of arboreal taxa, as it is mostly dominated by shrubby vegetation like Ericaceae. Further inland deserts occur. In the north, the Sahara (bestrepresented families being Asteraceae, Leguminosae and Poaceae (Ozenda 1991)) stretches from the Red Sea to the Atlantic. In the south the Namib desert covers the entire Namibian coast and parts of the Angolan and southern African coast. The transition between the Mediterranean forests and the Sahara, the Sahel region, the African Horn, and the area of the fynbos-to-desert transition in the south (the Kalahari desert) are classified as semi-deserts, where we find low densities of shrubby vegetation like Asteraceae. Poaceae-dominated systems are found throughout Africa. Grass savannahs are ubiquitous at the $15^{\circ} \mathrm{N}$ and the $20^{\circ} \mathrm{S}$ latitudes and in east African Rift Valley system. Edaphic grasslands (those controlled by soil conditions instead of climate, fire regimes,

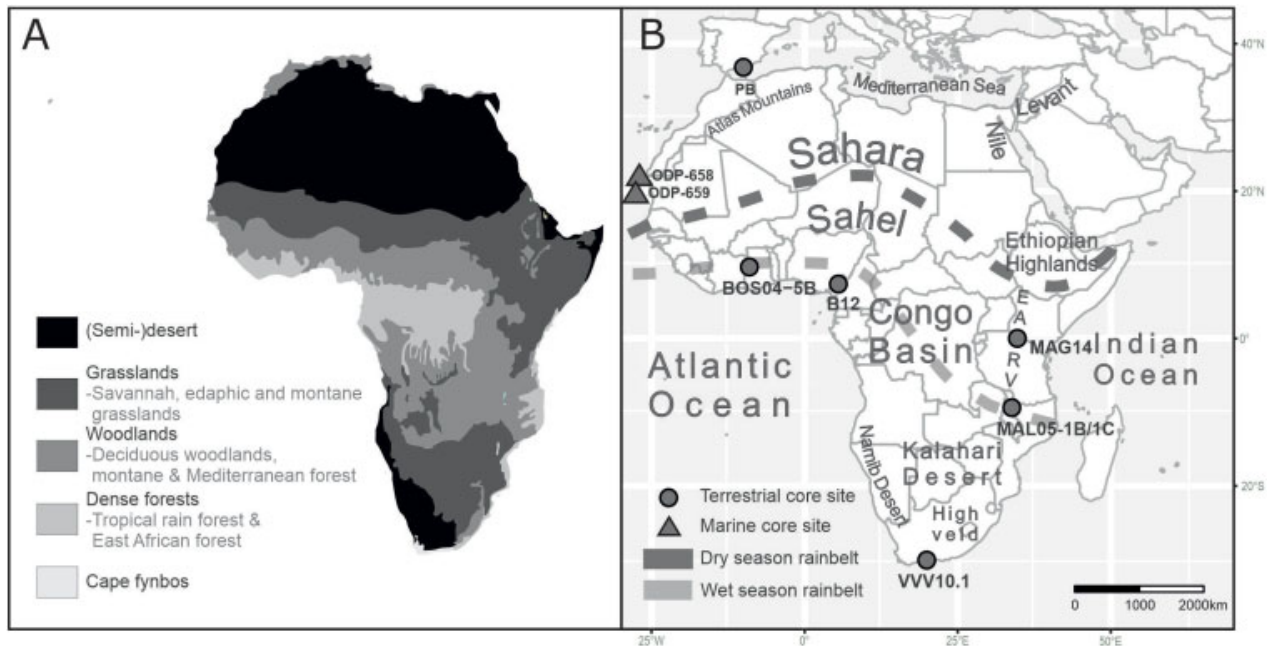

Figure 2. (A) Modern African vegetation simplified from Dupont (2011). (B) Location of the seven pollen records obtained from lake settings relevant to past vegetation change in Africa relevant to hominin evolution over the last 500 thousand years. PB = Padul Basin, Spain (Torres et al. 2020), VVV10.1= Vankervelsvlei, South Africa (Quick et al. 2016), MAG14 = Lake Magadi, Kenya (Owen et al. 2018), MAL05-1B/1C (MAL05-1B and MAL05-1C) = Lake Malawi, Malawi (Beuning et al. 2011; Ivory et al. 2018), B12 = Lake Bambili, Cameroon (Lézine et al. 2019), and BOS04-5B = Lake Bosumtwi, Ghana (Miller and Gosling 2014). Marine cores presented for additional context are ODP-658 (Dupont 1989; Dupont and Hooghiemstra 1989) and ODP-659 (Tiedeman et al. 1994). 
or herbivory) can be found in Angola, Zambia and the Democratic Republic of Congo. Montane grasslands are prevalent in the arid high-altitude regions of central Africa, the East-African Highlands and the South-African Highveld. Forested areas are restricted to the moist equatorial regions and the high elevation Afromontane forests found in East-Africa and South Africa. Tropical rainforests extend across the basin of the Congo River and its tributaries but are also found along the coast of western Africa, spreading from southern Guinea all the way east to southern Cameroon. At higher latitudes tropical moist forests transitions into deciduous forests/woodlands as the vegetation becomes increasingly influenced by seasonality in precipitation.

To understand how vegetation association, and thus potential habitats or barriers for early $H$. sapiens, varied over time it is important to understand the climatic factors that relate to vegetation formation and how this has changed. Orbital precession, with a c. 21,000 year cycle, has a strong influence on long-term climate change in the low elevation tropics (Clement et al. 2004). Precession directly affects when in the year the earth is closest to the sun, and thus governs the amount of insolation received during each season. The strength and the annual latitudinal reach of the tropical rain belts are governed by changes in insolation that consequently are directly influenced by changes in the precessional cycle. Specifically, at the peak in the precessional cycle, the monsoons can reach further northwards into the otherwise arid part of Africa (Dupont and Hooghiemstra 1989; Frumkin et al. 2011). This additional moisture delivery has a significant impact on vegetation cover, and climate-vegetation simulations suggest that this processional climate signal is a dominant control on vegetation change at low latitudes (Gosling and Holden 2011).

\subsubsection{Ecological boundaries and refugia for archaic Homo sapiens}

Environmental changes, prompted by changes in precipitation related to multi-millennial-scale climate oscillations have been shown to shape and maintain ecological boundaries that eventually limited gene-flow between populations in lions (Panthera leo), thereby creating distinct genetic clades (Bertola et al. 2016). Similar biogeographic patterns of speciation seem to exist in a wide array of African mammals (list of references in Bertola et al. 2016), and the same mechanism has been postulated for archaic H. sapiens populations (Scerri et al. 2018). Habitats largely inhospitable to archaic $H$. sapiens, such as arid deserts and dense rainforests (Bailey et al. 1989; Blome et al. 2012; Coulthard et al. 2013), expanded and retracted over time-scales of millennia in response to orbital scale vegetation change (Dupont 2011). The expansion of deserts and rainforests often occurred at the expense of open ecosystems (e.g. savannahs) which are thought to have been the preferred habitat of early hominins based on the close affinity between archaeological evidence of hominins and grasslands ecosystems (Cerling et al. 2011; Larrasoaña et al. 2013). It can therefore be hypothesized that climatic conditions that caused a decline in savannah ecosystems in favour of deserts and rainforests would have caused a loss of habitat for archaic $H$. sapiens. This loss of hospitable environment could have lead to the migration of some $H$. sapiens populations and a loss in connectivity between others and thus generated the population structure needed for independent evolution. As the remaining hominin populations became more isolated they likley retreated to 'refugia' (isolated regions where environmental conditions allowed humans to persevere amidst inhospitable conditions (Mirazón Lahr and Foley 2016)) which have also been highlighted as catalysts for evolutionary change in $H$. sapiens (Stewart and Stringer 2012).

\subsubsection{Palaeoenvironmental reconstructions}

Marine palynological records have been used to provide a pan-African view of vegetation change (Dupont 2011). The advantage of marine records is that they are well-dated and yield the ability to record large scale vegetation change from a wide source area (Castañeda et al. 2016; Dalibard 
et al. 2014; Hooghiemstra et al. 2006; Jahns et al. 1998; Zhao et al. 2003). However, interpretation of past vegetation cover from marine pollen records is challenging (Frédoux 1994; Hooghiemstra et al. 1986) because of the inherent wide pollen source area, which means that the signal is influenced by: (i) the intricate complexity of wind current and fluvial dynamics that muddle the opportunity to precisely identify the source (Dupont et al. 2000), and (ii) a low spatial resolution that makes it impossible to see vegetation dynamics on a local scale. For example in regions dominated by arid vegetation but where lush vegetation boarders rivers, the marine pollen signal could be biased towards the lush vegetation as it produces relatively more pollen and they are easily transported into the ocean sediments. In contrast to the marine records, the pollen found within a lake (diameter 5-20 km) likely reflects local/extra-local (10-100 s m) and regional (1-10 s km) vegetation (Jacobson and Bradshaw 1981). Therefore, lacustrine pollen records are more suitable to reconstruct vegetation changes at the local and regional scales, which allows the habitats of archaic $H$. sapiens to be investigated.

\subsection{SITE SELECTION}

To provide the vegetational context in which early $H$. sapiens evolution took place we selected palaeovegetation records that contain information relevant from across Africa. The most appropriate records were chosen to represent each of five African regions (northen, southern, eastern, western and central) based on two criteria:

- Sedimentary record covering at least the last c. $100 \mathrm{ka}$.

- At least one proxy of past vegetation change has been published from the record.

Six lacustrine records were identified meeting these criteria from in, and around, the African continent (Table 1; Figure 2B).

\subsection{LONG-TERM VEGETATION CHANGES IN AFRICA}

One record of past vegetation was obtained from each region, except for eastern Africa, from which two were obtained (Figure 3). The records ranged from c. 90 ka to $800 \mathrm{ka}$ in duration and past vegetation information was obtained from fossil pollen at all sites. To place these records in the context of global climatic change we refer to the global glacial (cool) and interglacial (warm) Marine Isotope Stages (MIS) as defined by Imbrie et al. (1984). The six records are now reviewed in turn, in the order of the earliest archaeological evidence of $H$. sapiens in the vicinity of the core site: (i) Padul Basin, northern Africa region (Torres et al. 2020), (ii) Vankervelsvlei, southern Africa region (Quick et al. 2016), (iii) Lake Magadi, eastern Africa region (Owen et al. 2018), (iv and v) Lake Malawi, eastern Africa (Beuning et al. 2011; Ivory et al. 2018), (vi) Lake Bambili, central Africa (Lézine et al. 2019), and (vii) Lake Bosumtwi, western Africa (Miller and Gosling 2014).

\subsubsection{Padul Basin, Spain}

No lacustrine sedimentary record spanning $c .100 \mathrm{kyr}$ has, to date, been recovered or analysed for pollen from continental north-west Africa. Therefore, the sediment record from the Padul Basin (PB) from the Granada province in south-east Spain (Torres et al. 2020) was chosen to provide the closest available vegetational context for the earliest known $H$. sapiens found to date (Figure 3A). The archaic H. sapiens fossils found at Jebel Irhoud (Morocco) have been dated to $315 \pm 34 \mathrm{ka}$ and include facial bones (Hublin et al. 2017). The PB sediment core was retrieved from a peat bog inside a closed flat depression, with a catchment area of $44 \mathrm{~km}^{2}$, located $720 \mathrm{~m}$ 
Table 1. List of selected lacustrine pollen records and metadata.

\begin{tabular}{|c|c|c|c|c|c|c|c|c|c|c|}
\hline Region & Site name & Core name & Country & $\begin{array}{l}\text { Latitude } \\
\text { Longitude }\end{array}$ & $\begin{array}{l}\text { Core } \\
\text { length } \\
(m)\end{array}$ & $\begin{array}{l}\text { Dating } \\
\text { method }\end{array}$ & $\begin{array}{l}\text { \# age } \\
\text { samples }\end{array}$ & $\begin{array}{l}\text { Timescale } \\
\text { (ka) }\end{array}$ & Referenc & $\begin{array}{l}\text { Earliest } \\
\text { human } \\
\text { evidence } \\
\text { (ka) }\end{array}$ \\
\hline $\begin{array}{l}\text { Northern } \\
\text { Africa }\end{array}$ & $\begin{array}{l}\text { Padul } \\
\text { Basin }\end{array}$ & PB & Spain & $\begin{array}{r}37^{\circ} 01^{\prime} 01^{\prime \prime} \mathrm{N} \\
3^{\circ} 36^{\prime} 07^{\prime \prime} \mathrm{W}\end{array}$ & 107 & $\begin{array}{l}{ }^{14} \mathrm{C} / \mathrm{U} / \mathrm{Th} / \\
\text { palaeomag }\end{array}$ & 27 & 800 & $\begin{array}{l}\text { Torres et al. } \\
(2020)\end{array}$ & 315 \\
\hline $\begin{array}{l}\text { Southern } \\
\text { Africa }\end{array}$ & Vankervelsvlei & VVV10.1 & $\begin{array}{l}\text { South } \\
\text { Africa }\end{array}$ & $\begin{array}{l}34^{\circ} 044.58^{\prime \prime} \mathrm{S} \\
22^{\circ} 54^{\prime} 15.06^{\prime \prime} \mathrm{E}\end{array}$ & 4 & ${ }^{14} \mathrm{C} /$ Luminescence & 6 & 110 & $\begin{array}{l}\text { Quick et al. } \\
\text { (2016) }\end{array}$ & 260 \\
\hline $\begin{array}{l}\text { Eastern } \\
\text { Africa }\end{array}$ & $\begin{array}{l}\text { Lake } \\
\text { Magadi }\end{array}$ & MAG14 & Kenya & $\begin{array}{l}1^{\circ} 54^{\prime} 3.56^{\prime \prime} \mathrm{S} \\
36^{\circ} 14^{\prime} 48.52^{\prime \prime} \mathrm{E}\end{array}$ & 194 & $\begin{array}{c}{ }^{14} \mathrm{C} / \mathrm{Ar}-\mathrm{Ar} / \\
\mathrm{U}-\text { series }\end{array}$ & 18 & 1000 & $\begin{array}{l}\text { Owen et al. } \\
\text { (2018) }\end{array}$ & 195 \\
\hline $\begin{array}{l}\text { Eastern } \\
\text { Africa }\end{array}$ & $\begin{array}{l}\text { Lake } \\
\text { Malawi }\end{array}$ & $\begin{array}{l}\text { MAL05- } \\
1 \mathrm{C}\end{array}$ & Malawi & $\begin{array}{l}11^{\circ} 17^{\prime} 37^{\prime \prime} \mathrm{S} \\
34^{\circ} 26^{\prime} 04^{\prime \prime} \mathrm{E}\end{array}$ & 90 & ${ }^{14} \mathrm{C} /$ Luminescence & 25 & 135 & $\begin{array}{l}\text { Beuning } \\
\text { et al. } \\
(2011)\end{array}$ & - \\
\hline $\begin{array}{l}\text { Eastern } \\
\text { Africa }\end{array}$ & $\begin{array}{l}\text { Lake } \\
\text { Malawi }\end{array}$ & $\begin{array}{l}\text { MAL05- } \\
1 \mathrm{~B} / 1 \mathrm{C}\end{array}$ & Malawi & $\begin{array}{l}11^{\circ} 17^{\prime} 37^{\prime \prime} \mathrm{S} \\
34^{\circ} 26^{\prime} 04^{\prime \prime} \mathrm{E}\end{array}$ & 170 & $\begin{array}{l}{ }^{14} \mathrm{C} / \text { palaeomag/ } \\
\mathrm{Ar}-\mathrm{Ar}\end{array}$ & 41 & 600 & $\begin{array}{l}\text { Ivory et al. } \\
(2018)\end{array}$ & - \\
\hline $\begin{array}{r}\text { Central } \\
\text { Africa }\end{array}$ & $\begin{array}{l}\text { Lake } \\
\text { Bambili }\end{array}$ & B12 & Cameroon & $\begin{array}{l}6^{\circ} 0^{\prime} 19.56^{\prime \prime} \mathrm{N} \\
10^{\circ} 15^{\prime} 46.14^{\prime \prime} \mathrm{E}\end{array}$ & 26.6 & ${ }^{14} \mathrm{C}$ & 29 & 90 & $\begin{array}{l}\text { Lézine et al. } \\
\text { (2019) }\end{array}$ & 30 \\
\hline $\begin{array}{l}\text { Western } \\
\text { Africa }\end{array}$ & $\begin{array}{l}\text { Lake } \\
\text { Bosumtwi }\end{array}$ & $\begin{array}{l}\text { BOS04- } \\
5 \mathrm{~B}\end{array}$ & Ghana & $\begin{array}{l}6^{\circ} 30^{\prime} 6.04^{\prime \prime} \mathrm{N} \\
1^{\circ} 24^{\prime} 52.14^{\prime \prime} \mathrm{W}\end{array}$ & 295 & $\begin{array}{c}{ }^{14} \mathrm{C} / \text { Luminescence/ } \\
\text { U-series/Ar-Ar }\end{array}$ & 135 & 1000 & $\begin{array}{l}\text { Miller and } \\
\text { Gosling } \\
(2014)\end{array}$ & 12 \\
\hline
\end{tabular}




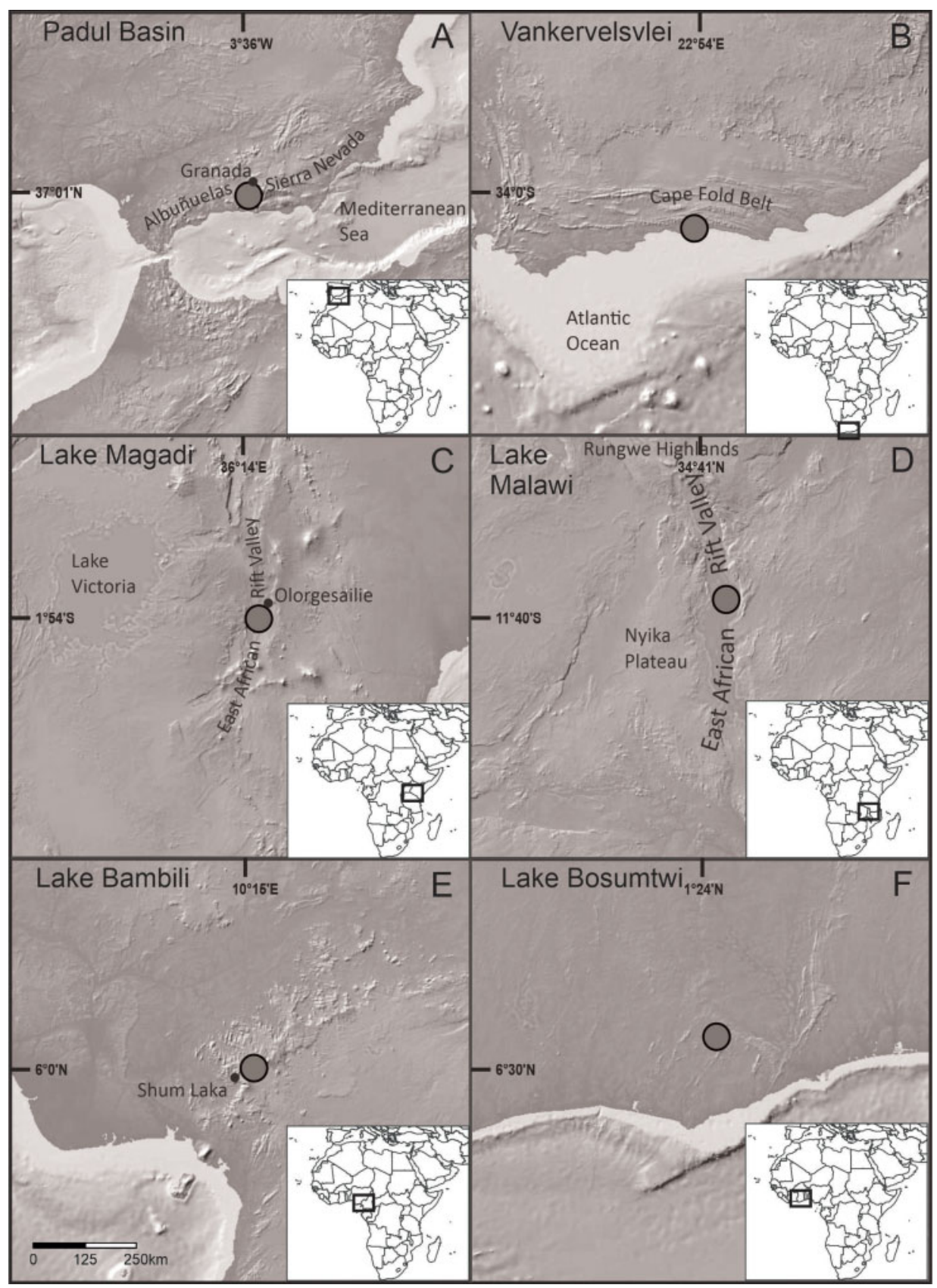

Figure 3. Regional topographic context (main panels) and continental geographic contexts (inset panels) of lacustrine records reviewed in this study. (A) Padul Basin (Spain). (B) Vankervelsvlei (South Africa). (C) Lake Magadi (Kenya). (D) Lake Malawi (Malawi). (E) Lake Bambili (Cameroon). (F) Lake Bosumtwi (Ghana). 
above sea level ( $\mathrm{m}$ asl), and enclosed by mountains to the west (Albuñuelas range) and east (the Sierra Nevada). The altitudinal range of the mountains around the Padul Basin provides habitat for a wide variety of vegetation; from evergreen oak groves below $700 \mathrm{~m}$ to pine forests at the higher elevations (Rivas-Martínez 1987). Importantly, even though PB and Jebel Irhoud are located $c .750 \mathrm{~km}$ apart, they still encompass the same temperate Mediterranean Köppen climate area (Chen and Chen 2013; Rubel and Kottek 2010).

Pinus dominates the pollen record from PB during MIS 13.13 (c. $500 \mathrm{ka}$ ), making up c. $60 \%$ of the pollen spectra while the presence of Poaceae is low and accounts for only $10 \%$. Pinus and Poaceae start to diminish between MIS 13.11 and 12.1 (480-425 ka) as mesophilic taxa (Acer, Alnus, Quercus, Corylus, Carpinus, Fraxinus, Ulmus) and riparian taxa (Cornus, Populus, Salix) become more abundant. Subsequently, a period of low pollen preservation is found until the start of MIS 11.2 (385 ka), which ends with a pollen assemblage dominated by Pinus that, in turn, transitions in to a steppic vegetation (Artemisia, Ephedra) over a c. $45 \mathrm{kyr}$ period. The transition to steppic vegetation is not smooth, with a peak in Pinus (70\%) around the end of MIS $11(360 \mathrm{ka})$, followed by a rapid decline to $c$. 10\% at the start of MIS $10.2(341 \mathrm{ka})$. Poaceae has a low presence throughout this transitional period, averaging c. 10\%. Between MIS 10.2 and MIS 9.1 (341-310 kyr BP), the pollen assemblage is relatively diverse. Throughout this period Poaceae declines from c. $40 \%$ c. 310 ka to $c .10 \%$, while Pinus, steppic taxa and Amaranthaceae all see a marked rise. From the start of MIS 8.5 (287 ka) Poaceae rises to its maximum abundance (c. $80 \%$ ) in the entire record and Pinus, the most prominent taxon throughout the palynological record, is reduced to $c$. 5\%. The dominance of the pollen assemblage by Poaceae continues for c. $5 \mathrm{kyr}$ and then recedes back to $c .10 \%$ by $280 \mathrm{ka}$. From $280 \mathrm{ka}$ until $170 \mathrm{ka}$ Poaceae is $c .10 \%$, and Pinus is c. 40\%, while Quercus is most abundant between MIS 7.5-6.6 (238-183 ka). These episodes between MIS 7.5 and $6.6(238-183 \mathrm{ka})$ are also characterized by a growing presence of steppic taxa, especially within the timeframe where Pinus percentages show lower values. Between $c .183 \mathrm{ka}$ and $c .170 \mathrm{ka}$ there is a hiatus in the pollen record. Pollen is recorded again halfway through MIS 6 (c. $170 \mathrm{ka})$, starting with a high abundance of Pinus $(c .80 \%)$ that declines to $30 \%$ at $130 \mathrm{ka}$, with steppic taxa and Poaceae present throughout. Steppic taxa and Poaceae then practically disappear from the record during MIS 5 (122-71 ka), but Pinus rises again reaching c. $80 \%$ at $120 \mathrm{ka}$. Pinus percentages keep on fluctuating around $50 \%$ for the remainder of the record up until the present, and the distinct changes in the vegetational compositions are due to fluctuations in pollen percentages of other taxa. The shrubby xerophilous taxa show a stable representation of $c .15 \%$ during the MIS 4-2 interval (65-12 ka), after which their presence disappears. Similar trends can be found in the steppic taxa, which also steadily increase up to $40 \%$. When steppic taxa disappeard Poaceae shows another peak, contributing close to $50 \%$ to the pollen sum; however, Poaceae, xerophilous (Amaranthaceae) and steppic (Artemisia, Ephedra) taxa are no longer represented towards the end of $\mathrm{PB}$ record.

\subsubsection{Vankervelsvlei, South Africa}

The sediment core recovered from Vankervelsvlei wetlands $\left(34^{\circ} 0^{\prime} 44.58^{\prime \prime} \mathrm{S}, 22^{\circ} 54^{\prime} 15.06^{\prime \prime} \mathrm{E}\right)$ (VVV10.1) is located on the southern coastal plains of South Africa (Quick et al. 2016), a stretch of land bordering the Atlantic Ocean in the south, isolated from inland South Africa by the mountainous Cape Fold Belt (Figure 3B). These wetlands encompass a catchment of c. $0.5 \mathrm{~km}^{2}$ and are situated on the landward edge of the Wilderness embayment at an elevation of $153 \mathrm{~m}$ asl. Vankervelsvlei is hydrologically isolated from the regional aquifer and fed exclusively by rainfall (Roets et al. 2008). Today the local vegetation is dominated by Cyperaceae mats floating on the wetland, fynbos-dominated vegetation (e.g. Passerina, Ericaceae, Leucadendron and Restionaceae) on the wetland's margins, and Afrotemperate forest types to the north (including Ocotea, Olea and Podocarpus). Compton (2011) proposed that these isolated coastal plains could be the geographical point of origin for AMH, suggesting the periodic sea-level changes 
induced by interglacial-glacial cycles provoked competition and innovation. However, subsequent research, based on mitochondrial DNA lineages, indicated that $H$. sapiens migrated to the southern African coast from wetlands in modern-day Botswana c. $100 \mathrm{ka}$ (Chan et al. 2019); although these interpretations have been subsequently challenged (Schlebusch et al. 2021) so uncertainty prevails. However, the region remains important from an evolutionary perspective because it contains the Blombosgrot cave which is one of the most prominent archaeological sites in southern Africa regarding the cultural development in $H$. sapiens (Douze et al. 2015). The Blombosgrot cave, located $160 \mathrm{~km}$ west of Vankervelsvlei, has been inhabited since at least $140 \mathrm{ka}$ (Jacobs et al. 2006) and contains toolkits providing evidence for long-term planning and an elementary knowledge of chemistry c. $100 \mathrm{ka} \mathrm{(Henshilwood} \mathrm{et} \mathrm{al.} \mathrm{2011).}$

The VVV10.1 record has a basal age in MIS 6.3 (146 ka), but no pollen was preserved until MIS $5.5(122 \mathrm{ka})$, with another hiatus in the record during MIS 3.0-2.0 (24-12 ka). Afromontane forest taxa, predominantly Podocarpus, characterize the early sections but are barely found throughout the rest of the pollen record. Percentages for Afromontane taxa vary from $c .5$ to $c .15 \%$ in MIS 5.4-5.3 (107-99 ka), but gradually decline until they are lost from the record in late MIS 5 and only sporadically occur in trace amounts thereafter. The most dominant vegetational elements between MIS 5.4 and 5.3 (107-99 ka) are the fynbos taxa. Among the fynbos taxa, Ericaceae is particularly abundant (reaching c. $40 \%$ ), with Stoebe (20\%) also significant. Subsequently, Ericaceae abundance remains high (average c. 60\%) until MIS 3.0 (24 ka). The Ericaceae record starts declining around the transition to MIS 2.0 to about $45 \%$. In the following c. $15 \mathrm{kyr}$ pollen is poorly preserved, but Ericaceae ends up with percentages less than $5 \%$ in the most recent samples, which are dominated by unprecedented high values of Cyperaceae of over $40 \%$.

\subsubsection{Lake Magadi, Kenya}

Lake Magadi is a seasonally flooded pan with a surface catchment of $c .100 \mathrm{~km}^{2}$, situated $606 \mathrm{~m}$ asl in the south Kenyan part of the east African Rift Valley (Figure 3C). The Lake Magadi record (MAG14-2A) (Owen et al. 2018), was chosen based on its proximity (c. $25 \mathrm{~km}$ ) to the Olorgesailie archaeological site (Behrensmeyer et al. 2002) and its length; covering the past one million years. The core was drilled as part of The Hominin Sites and Palaeolakes Drilling Project (HSPDP) initiative (Campisano et al. 2017). The Olorgesailie site is of particular interest because its archaeological surveys document a transition from the Acheulean to the Middle Stone Age mode of stone toolmaking between c. 320 and 305 ka (Brooks et al. 2018; Deino et al. 2018). This period of technological and cultural development is itself associated with the evolution of H. sapiens. Furthermore, this core is also the closest to the archaeological sites which have yielded the earliest recognized anatomically modern $H$. sapiens fossils in eastern-Africa, Omo Kibish (c. $195 \mathrm{kyr} \mathrm{BP}$ ) and Herto (c. $160 \mathrm{kyr}$ BP) at 700 and $1400 \mathrm{~km}$ respectively, both in Ethiopia.

The pollen record of MAG14-2A shows vegetation change over the last $500 \mathrm{ka}$, although the MIS 11.2 to 9.0 interval (375-303 ka) is devoid of pollen. Pre-500 ka vegetation was dominated locally by Poaceae and Cyperaceae, both making up $80 \%$ in at least one sample dated before the onset of MIS 13.13 (502 ka). Afromontane forest taxa make up the majority of the regional pollen signal, and Podocarpus dominates this regional signal with percentages of $c$. $80 \%$, indicating a significant presence of arboreal taxa. By MIS 13 the pollen spectra seem to represent dry open grassland, almost completely comprised of Poaceae and deprived of arboreal taxa, except for low (c. 10\%) percentages of Podocarpus. Poaceae shows a stable representation during the subsequent $125 \mathrm{ka}$, while both Cyperaceae and Podocarpus show an almost linear increase in representation. Although the following $75 \mathrm{kyr}$ were not sampled, percentages of both local and regional pollen taxa seem to remain stable, potentially suggesting stable environmental conditions during this interval. Vegetation diversifies with the onset of MIS 6.6 (183 ka), during which Olea, Juniperus, Commiphora, Acacia and Amaranthaceae fluctuate between 0 and $40 \%$. 


\subsubsection{Lake Malawi, Malawi}

The sediment records MAL05-1B and -1C (Beuning et al. 2011; Ivory et al. 2018) were retrieved from Lake Malawi, the southernmost lake in the east African Rift Vally system (Figure 3D). Lake Malawi at $472 \mathrm{~m}$ asl has a surface area of $c .29,500 \mathrm{~km}^{2}$ and a catchment area of $c .65,000 \mathrm{~km}^{2}$ bordering the Rungwe volcanic highlands in the north and the Nyika plateau in the west. The mountainous topography means that the modern vegetation surrounding Lake Malawi is characterized by Afromontane forests (Podocarpus) and Afromontane grasslands in the west, while scrubland and woodland vegetation types can be found east of Lake Malawi. Despite the absence of AMH fossils in the vicinity of Lake Malawi, the vegetation records from the MAL05-1B/1C records are still relevant to AMH dispersal. The location of origin of AMH and the direction of their dispersal events is still debated; both southern Africa (e.g. Jacobs et al. 2008; Schlebusch et al. 2017) and north-eastern Africa (e.g. Lamb et al. 2018; Walter et al. 2000) have been proposed as regions harbouring the population of early humans that would ultimately disperse throughout the rest of the world. This makes Lake Malawi a likely passing point in the corridor used in either a northward or a southward dispersal of these AMH.

MAL05-1B and MAL05-1C together comprise 170 metres of sediment, of which 1C represents the youngest 62 metres and 1B the older 108. The MAL05-1B/1C pollen stratigraphy shows distinct antiphasing between periods of high arboreal (i.e. Podocarpus) pollen and periods with a distinct presence of non-arboreal (notably Poaceae) pollen. These arboreal phases are marked by analogous trends in other Afromontane taxa (e.g. Apodytes, Ericaceae, Ilex, Juniperus, Kiggelaria, Myrtaceae, Olea and Syzygium), and palynological studies on contemporary Afromontane forest suggests that Podocarpus percentages of $>40 \%$ indicate dense forests, reaching all the way down to the shores of Lake Malawi (Ivory et al. 2018). The non-arboreal phases (indicated by grasses, herbs like Amarathaceae or woodland trees such as Acacia) on the other hand are indicative of dry woodland/wooded grassland type of ecosystems. In total the MAL05-1B/1C cores both record seven forest phases and seven grassland phases over the past 500 kyr. These start with a grassland phase (c. 75\% Poaceae) lasting until MIS 12.4 (470 ka), when an extensive forested period is initiated for the subsequent $200 \mathrm{kyr}$. During this phase Podocarpus percentages fluctuate between $c$. 45\% (MIS 12.32 and MIS 11.2, 450 and $375 \mathrm{kyr}$ respectively) and c. 10\% (MIS 9.2, $325 \mathrm{kyr}$ ), averaging on c. 30\%. While Podocarpus percentages of $10 \%$ are low, arboreal taxa still maintain a relative dominance over non-arboreal pollen due to high percentages of Celtis (c. 15\%), especially during MIS 11.2. Subsequent transitions between forest and open ecosystems are more frequent. Throughout the remainder of MAL05-1B we find four more grassland phases; MIS 8.4-7.5 (274-241 ka), MIS 7.2-7.0 (209-193 ka), MIS 6.6-6.5 (189-165 ka) and MIS 6.2 (142-137 ka), interspersed with forest phases at MIS 7.5-7.2 (241-209 ka), MIS 6.6 (193-189 ka) and MIS 6.5-6.2 (165-142 ka).

The base of record MAL05-1C (Beuning et al. 2011) is dated to the later part of MIS 6.2 (135 ka), and immediately records an increase in Podocarpus from near absence to c. 35\% during the period MIS 6.2-6.0 (135-128 ka). A similar increase in Podocarpus is noted at the start of MIS 5 (between MIS 5.5 and 5.4 (122-107 ka)). Both these increases in Podocarpus are concomitant with an opposite trend in Poaceae percentages, which shows values of $80 \%$ between MIS 6 and 5.5 (122 ka), but 40-30\% before and after this interval. The halfway point of MIS 5 is marked by a decline of Podocarpus percentages again coeval with another increase in Poaceae. Poaceae reaches its maximum at MIS 5.2 (87 ka) when its pollen make up nearly $100 \%$ of the pollen spectra. Samples from MIS 4 onwards show Poaceae stabilizing at $40 \%$, a value that continues throughout the rest of the record, except for a short increase to $c .60 \%$ and a short depression to c. 20\% at MIS 4.2 (65 ka) and $3.3(53 \mathrm{ka})$, respectively. Meanwhile, Podocarpus enters the regional vegetation again in MIS 4, showing percentages of $10 \%$ over a period of c. $10 \mathrm{kyr}$ and reaching c. $30 \%$ between MIS 4.2 and 3.3 before it decreases again to $10 \%$, a value which is maintained throughout the remainder of the record. Prior to the peak in Podocarpus, 
peaks in other montane and woodland taxa (e.g. Acalypha, Acanthaceae, Blighia, Combretaceae, Craterispermum, Commiphora, Lannea, Maclura and Mimosaceaeas), as well as maximum values in evergreen trees (e.g. Alchornea, Celtis, Faurea, Ixora, Macaranga, Moraceae, Myrica and Trema), are shown in the pollen record (c. 10\%, 20\% and $20 \%$, respectively), after which all three groups continue at $c .10 \%$ throughout the rest of the record.

\subsubsection{Lake Bambili, Cameroon}

The inclusion of Lake Bambili's pollen record (B12), given it has the shortest timeframe (90 ka) in this review, is justified by its close geographical proximity to the Cameroonian Shum Laka archaeological site $\left(5^{\circ} 51^{\prime} 31^{\prime \prime} \mathrm{N}, 10^{\circ} 4^{\prime} 40^{\prime \prime} \mathrm{E}\right.$ ), situated c. $20 \mathrm{~km}$ southwest of Lake Bambili (Figure $3 \mathrm{E}$ ). The oldest layer containing evidence of the presence of $H$. sapiens is dated $c .30 \mathrm{ka}$ (Lipson et al. 2020), while the rest of the archaeological record also displays evidence of significant societal developments such as a transition period in tool use (sometimes referred to as the 'Stone to Metal age') between the end of the Later Stone Age at $8 \mathrm{ka}$ and the beginning of the Iron Age at $2.5 \mathrm{ka}$, as well as evidence for foundation and early stages of agriculture (Lavachery 2001). Lake Bambili is a high-altitude ( $2273 \mathrm{~m}$ asl) crater lake, currently enclosed locally by Afromontane forests characterized by the conifer Podocarpus milanijanus (Lézine et al. 2019), while the vegetation transitions to Afroalpine grasslands at higher altitudes and a mosaic of submontane forests and savannahs at lower altitudes (Lézine et al. 2013).

The initial aim of the palynological record presented in Lézine et al. (2019) was to reconstruct the history of Afromontane forests and their responses to glacial-interglacial cycles. Nevertheless, the pollen assemblages at Bambili can also be used to infer the landscape at a regional scale. The base of record B12 is dated to MIS $5.3(99 \mathrm{ka})$, and the record starts off with percentages of Podocarpus that decrease from c. $25 \%$ to $<5 \%$ just before the onset of MIS 5.1 ( $80 \mathrm{ka})$, while Poaceae show a coeval increase from $50 \%$ to $90 \%$. Trace amounts $(<5 \%)$ of other taxa are also present during this interval, e.g.Ericaceae, Olea, Asteraceae and Alchornea. This is immediately succeeded by a reversal in the trends of the two dominating taxa, and the representation of Podocarpus reaches $c$. $60 \%$ during MIS 5.1 at $75 \mathrm{ka}$, concurrent with a drop of Poaceae to $<5 \%$. During these extreme values, Olea, Syzygium, Schefflera and Asteraceae are also present in low quantities. Following the start of MIS 4 (71 ka), Podocarpus and Poaceae trends reverse again. Podocarpus remain practically absent $(<5 \%)$ from the record in the MIS 5.0-3.3 (71-53 ka) interval, all the while Poaceae holds a stable presence, fluctuating between $70-80 \%$ and Ericaceae and Asteraceae fluctuate around 5\%. MIS 3.3 sees Podocarpus reappearing in the record with $c$. $10 \%$, and Poaceae starts a slow decline to $40 \%$ at $45 \mathrm{ka}$, but both taxa return to percentages similar to those in the MIS 5.0-3.3 interval at the 37 ka mark until Poaceae starts decreasing MIS $2.2(19 \mathrm{ka})$. The gradual decrease of Poaceae lasts until it reaches $c .0 \%$ at $10 \mathrm{ka}$, and stays like this until c. $3 \mathrm{ka}$. During this $7 \mathrm{kyr}$ interval Podocarpus, Olea, Alchornea, Syzygium, and Schefflera reappear in the pollen record but get replaced by Poaceae in the modern vegetation (3-0 ka).

\subsubsection{Lake Bosumtwi, Ghana}

Core BOS04-5B was retrieved from Lake Bosumtwi, Ghana (Koeberl et al. 2007), with the intent of exploring the vegetational compositions of tropical western Africa in response to changes in regional climate during the Quaternary. Lake Bosumtwi $\left(6^{\circ} 30^{\prime} 6.04^{\prime \prime} \mathrm{N}, 1^{\circ} 24^{\prime} 52.14^{\prime \prime} \mathrm{W}\right)$ is situated in a meteorite impact crater formed $1.08 \pm 0.04$ million years ago (Jourdan et al. 2009) with a diameter of $c .11 \mathrm{~km}$ (Figure 3F). The bedrock and crater walls formed by this impact cause the lake's isolation from any regional bodies of water, precipitation being the only influx of water to the sedimentary archive. This closed hydrology makes the lake sensitive to regional climate change and precipitation in particular (Shanahan et al. 2012). The current lake surface of 
Bosumtwi is at $97 \mathrm{~m}$ asl, has a diameter of $8.5 \mathrm{~km}$ and a surface area of $52 \mathrm{~km}^{2}$. Situated in the 'Tropical and Subtropical Moist Broadleaf Forest' biome, Lake Bosumtwi occupies the transition between shrubby/woody savannah ecosystem to the north and moist forest ecosystem to the south (Olson et al. 2001). This setting makes the pollen record ideal for western-African vegetation reconstructions. Western Africa is notably underrepresented in the archaeological record, the oldest $H$. sapiens fossil being dated to only $12 \mathrm{ka}$ in southwestern Nigeria (Harvati et al. 2011).

An age-depth model is lacking in the initial publication presenting the pollen record of BOS04-5B (Miller and Gosling 2014). We follow the age model of Shanahan et al. (2013) and used by Miller et al. (2016) of the same core. The period MIS 14.2-12.33 (538-461 ka) is characterized by fluctuating Poaceae percentages (reaching values $>60 \%$ in the beginning and $<10 \%$ later in this interval) and the presence of moist broadleaf forest taxa like Celtis (c. $8 \%)$ and Moraceae (c. 15\%). At MIS 12.3-11.3 (461-405 ka) Poaceae increase up to $c$. 80\%, interrupted by a fall during MIS 12.31 (443 ka) to 40\%. In this period the moist broadleaf taxa show very low percentages. Cyperaceae reach c. $10 \%$ and montane tree Olea shows a single peak of $40 \%$ during MIS 12.31. Interval MIS 11.3-11.2 (405-375 ka) shows low (c. 20\%) Poaceae percentages, and an increase in the arboreal broadleaf taxa Celtis and Moraceae, as is the case for MIS 13.13-12.33 (502-461 ka), but this time there is also a notable presence of Macaranga (c. 10\%). Pollen spectra during MIS 11.2-10.2 (375-341 ka) resemble those found during the period of MIS 12.33-11.3, followed by a period of large fluctuations (from $<10 \%$ to $>80 \%$ ) in Poaceae percentages that lasts until MIS 7.3 (216 ka). During this period Moraceae continues to have a marked presence in the pollen record, whereas it seems that Celtis is replaced by montane Olea at MIS 8.5 (287 ka). Poaceae dominates the pollen signal from MIS 7.3 to MIS 6, with consistent percentages of $90 \%$ and virtually no other pollen types found in the sediment except for low presences of Cyperaceae and Olea (c. 10\%). In the upper part of the sediment column, during MIS 6-5.5 (183-122 ka) and MIS 2.2-0 (19-0 ka), Poaceae pollen is almost absent whereas taxa of moist broadleaf and the montane forest dominate.

\subsection{DISCUSSION}

We characterized vegetation as represented by the palynological records on a scale from open to closed (Figure 4). Our classification was done visually, using the pollen diagram provided in the original publication and based on the original interpretations by the authors. These characterisations are based on several factors: (i) the ratio Poaceae/arboreal pollen, (ii) the abundance of pollen reflecting shrubby taxa, (iii) (when provided) charcoal data, and (iv) relevant notes in the original publication. We relate the vegetation changes to the timing of the archaic $H$. sapiens transition to AMH and the $\delta^{18} \mathrm{O}$ record (Lisiecki and Raymo 2005); including the MISs notation following Imbrie et al. (1984) indicating either glacial or interglacial periods.

Here we interpret the vegetation structure based on the palynological record and try to environmentally contextualize the three steps in archaic $H$. sapiens migration as related to our proposed Inside-of-Africa environmental framework: (i) An initial dispersal event of archaic $H$. sapiens after our lineage split off $H$. neanderthalensis (c. 700-400 ka, MIS 18.2-11.3), (ii) a period of isolation imposed by regional-scale environmental conditions, limiting the exchange of both genes and cultural knowledge, thereby promoting intraspecific variation within the $H$. sapiens clade (c. 400-250 ka, MIS 11.2-8.2), and (iii) a period of increased interconnectivity and growing population sizes that lead to homogenization and, ultimately, the full suite of AMH characteristics (c. 250-100 ka, MIS 7-5.3). To complete the picture of vegetation change in Africa we briefly review the last $100 \mathrm{ka}$ and discuss the relevance of vegetation openness in this period for understanding the dispersal of hominins out of Africa (Blome et al. 2012; Carto et al. 2009; Tierney et al. 2017). 
A
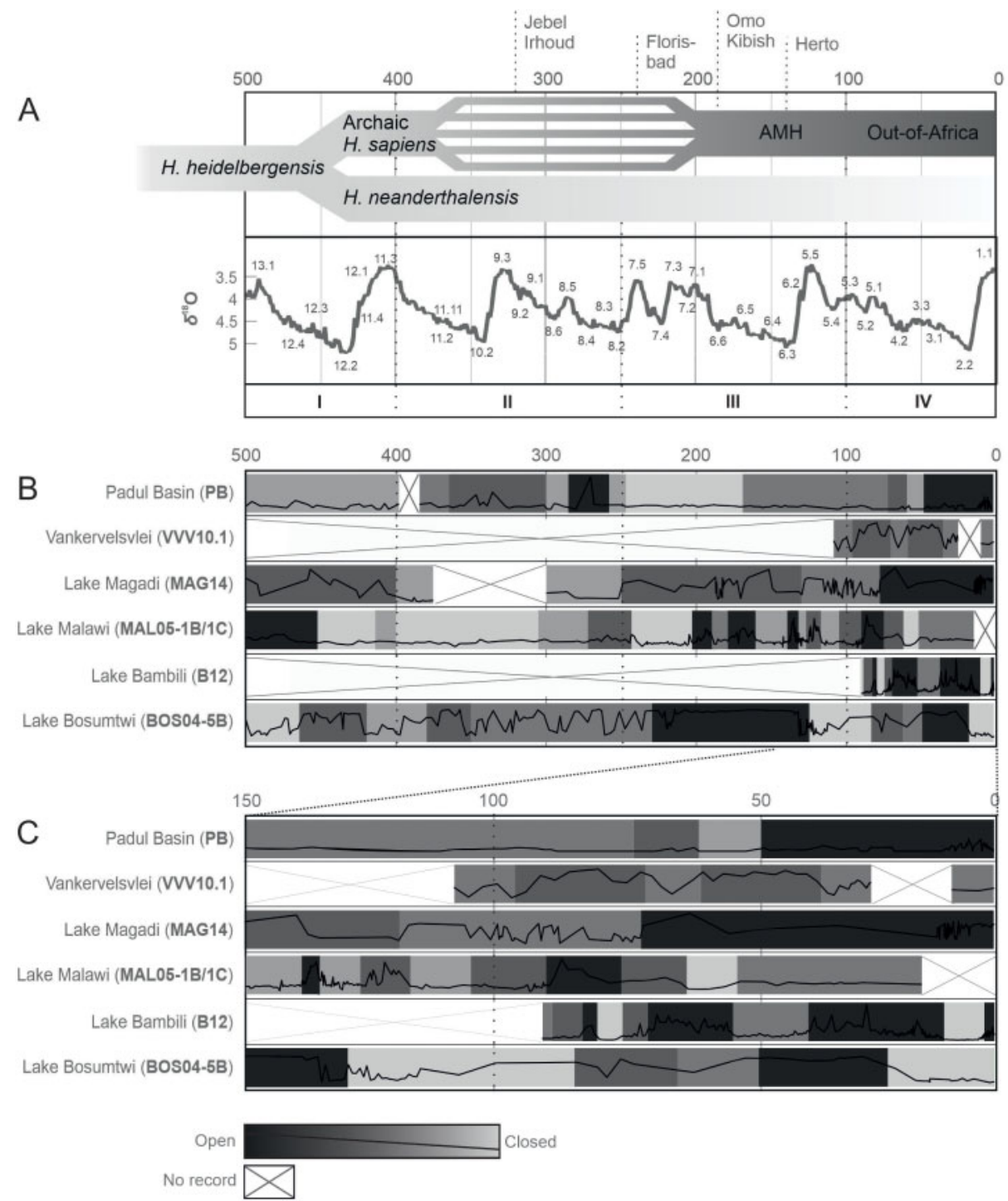

Figure 4. Hominin evolution and vegetation change in Africa over the last 500 thousand years. (A) Key archaeological sites (Grun et al. 1996; Hublin et al. 2017; McDougall et al. 2005; White et al. 2003), 'Inside-of-Africa' framework (Figure 1), and global climate change as indicated by global $\delta^{18} \mathrm{O}$ record (Lisiecki and Raymo 2005). Numbers on the $\delta^{18} \mathrm{O}$ panel indicate Marine Isotope Stage numbers as defined by Imbrie et al. (1984). (B) Degree of vegetation openness inferred from the ancient pollen records including respective open/close vegetation curve*. (C) Blown up view on the last 150 thousand years of vegetation change to show additional details. Indicated changes in the openness of the landscape are relative only to the pollen record itself. * The following data are plotted for each site: PB: Pinus\%/Poaceae\% (Torres et al. 2020), VVV10.1: Ericaceae\% (Quick et al. 2016), MAG14, MAL05-1B/1C, B12: Podocarpus\%/Poaceae\% (Beuning et al. 2011; Ivory et al. 2018; Lézine et al. 2019; Owen et al. 2018), BOS04-5B:

Poaceae\% (Miller and Gosling 2014). 


\subsubsection{Vegetational trends throughout Africa 500 to 400 ka (MIS 13.1-11.3)}

Currently, only four palynological records meeting our criteria are long enough to examine the vegetation change coeval with the initial radiation of archaic $H$. sapiens after their lineage split with $H$. neanderthalensis. These four records are the Padul Basin (PB; Torres et al. 2020) representing a change in the northern African region, Lake Magadi (MAG14; Owen et al. 2018), Lake Malawi (MAL05-1B; Ivory et al. 2018) in eastern Africa, and Lake Bosumtwi (BOS04-5B; Miller and Gosling 2014) in western Africa (Figure 4). We expected Africa in this period to host a relatively larger proportion of open vegetation that provided hospitable environments so the earliest members of the $H$. sapiens clade could disperse throughout Africa.

In northern Africa the relatively low resolution and multiple gaps in the PB pollen record make it difficult to discern variation in the vegetation cover during this period (Torres et al. 2020). However, the overall trend is apparent with the main arboreal taxon (Pinus) decreasing towards $400 \mathrm{ka}$. The loss of arboreal taxa could suggest that the vegetation structure became gradually more open; however, Poaceae does not replace the trees (also diminishing and absent 425-400 ka (MIS 12.1-11.3)). The loss of Pinus and Poaceae are also concomitant with a decline in total pollen influx rates, suggesting either reduced pollen productivity, a faster sediment accumulation, or poor preservation, all potentially indicative of more arid conditions. The high-resolution dust flux record from Atlantic core ODP 659 located at $18^{\circ} \mathrm{N}$ (Tiedeman et al. 1994) shows relevant information about climatic conditions in Saharan and sub-Saharan Africa. The 400-250 ka interval shows a maximum in dust outbreaks, indicative of dry conditions in Saharan Africa. It implicates that in this period the rain bringing ITCZ (where the northeast Trades meet the moisture loaden southwest Monsoon) hardly shifted into the northern hemisphere. Therefore, rains concentrated in equatorial and adjacent low southern hemisphere latitudes, allowing over large areas dense arboreal vegetation to expand. For the 400-250 ka interval the pollen record of site ODP 658 at $21^{\circ} \mathrm{N}$ (Dupont 1989; Dupont and Hooghiemstra 1989) is in support of substantial vegetation cover at equatorial latitudes. On the contrary, during the intervals 500-400 ka and 250-100 ka the dustflux shows significantly lower values (Tiedeman et al. 1994) and the monsoon front had more southern positions, implicating the monsoon front reached higher latitudes: Saharan Africa had wetter conditions and Africa at equatorial latitudes received less precipitation, allowing for a more open mosaic like vegetation pattern.

In the east African Rift Valley, between 500-400 ka, Lake Magadi and Lake Malawi both record open landscapes, savannahs in the north and wooded grasslands in the south, that transition into dense Afromontane forests over the course of the $100 \mathrm{kyr}$. Owen et al (2018) interpret this section of the Lake Magadi record as indicative of progressively more open vegetation, however, an examination of the pollen data indicates a wide variation in the abundance of arboreal taxa, e.g. Podocarpus fluctuates from near absence up to $c$. $80 \%$. We therefore also note that there were important woody components, and high dynamism, in the east African Rift Valley vegetation for much of the pre-400 ka part of the record. The exception is between 525-425 ka (MIS 13 and 12) where an abundance of Poaceae (80\%) suggests that savannah-like conditions dominated. This trend is almost exactly mirrored at Lake Malawi, where high Poaceae percentages (also 80\%) suggest grasslands to be present around the lake before $470 \mathrm{kyr}$, followed by an abrupt expansion of dense Afromontane forests in the latter part of this time interval (Ivory et al. 2018). This grassland period in the east African Rift Valley would likely have offered the most hospitable conditions to early hominins and, with the Congo Basin rainforest to the west of the east African Rift Valley, a passageway between southern Africa and the rest of the continent.

In western Africa no archaeological evidence for archaic H. sapiens during the pre-400 ka period has been found in the vicinity of Lake Bosumtwi, but environmental conditions do not necessarily exclude them from inhabiting the area. Miller et al. (2016) find significant grassland expansions in favour of forested areas as indicated by increasing percentages of Poaceae pollen. Grassland expansion in this region seems to be driven by increased dryness prompted by orbital 
cycles, as Poaceae peaks (sometimes even reaching 99\%) in record BOS04-5B are coeval with maxima in precessional amplitudes.

We find that during the period 500-400 ka (MIS 13.1-11.3) all of the available records show a degree of openness in the vegetation structure. The potential barriers to hominins are in western Africa in the early part of this period when the high representation of arboreal taxa shows a high forest cover (although this is not likely a dense rainforest). In the later part of this period, when poor pollen preservation prevails increased aridity is suggested in northern Africa.

\subsubsection{Vegetational trends throughout Africa between 400 and $250 \mathrm{ka}$ (MIS 11.2-8.2)}

To date, only four pollen records have been published that are long enough to examine the period of proposed less hospitable condition that limited dispersal, and thereby gene flow, in archaic H. sapiens; Padul Basin (PB; Torres et al. 2020) representing northern Africa, Lake Magadi (MAG14; Owen et al. 2018) and Lake Malawi (MAL05-1B/1C; Ivory et al. 2018) eastern Africa, and Lake Bosumtwi (BOS04-5B; Miller and Gosling 2014) western Africa (Figure 4).

At PB, following a gap in the record, the main arboreal taxa (Pinus) fluctuates widely from c. $80 \%$ to $c .5 \%$ between $c .380$ and 250 ka suggesting, apart from changes in aeolian pollen dispersal (Hooghiemstra et al. 1992) also major changes in the woody component. Within this period a change from Mediterranean (365-340 ka, MIS 11), to steppe vegetation (340-310 ka, MIS 10), and back to Mediterranean (310-295 ka, MIS 9.1-8.6) has been identified (Torres et al. 2001). Suggesting very dynamic vegetation with no discernable directional change in openness through this period.

The sedimentary record from Lake Magadi between 375 and 300 kyr BP was analysed for pollen (17 samples) but no pollen was recovered (Owen et al. 2018). Just before and after the hiatus in the record the percentage of aquatic taxa (e.g. Cyperaceae) and Afromontane taxa (e.g. Podocarpus) increase. The higher representation of aquatics could be interpreted as a lowering of the lake level providing more shallow water habitat for taxa such as Cyperaceae. The hiatus in the pollen record most likely represents a period of aridity when the basin (at least periodically) dried out and consequently little or no pollen is preserved; suggesting that through MIS 9 warmer conditions resulted in evaporation exceeding precipitation and so reduced the lake level. The more arid conditions potentially formed a barrier that disconnected northern Africa from southern Africa, thereby limiting any hominin dispersal between these two regions. In strong contrast to the arid conditions at Lake Magadi, we see that Lake Malawi hosts a vegetational community that is highly dominated by arboreal pollen from c. 470 to $270 \mathrm{ka}$. It is therefore suggested in Ivory et al. (2018) that the rigid ecosystem changeovers elucidated by MAL05-1B are a product of the response of local vegetation to the regional precipitation regime, comprising of a feedback between moisture recycling in Lake Malawi and eccentricity mediated summer insolation (Ivory et al. 2016). Still, since we characterise Lake Malawi as being surrounded by dense (Afromontane) forests, it is in line with our hypothesis of inhospitable vegetational cover during the period 400-250 ka, albeit for a different reason than at Lake Magadi.

The Lake Bosumtwi record shows wide fluctuations between c. $90 \%$ and c. $10 \%$ in the abundance of Poaceae between 400 and 250 ka which was initially interpreted as abrupt highmagnitude transitions between grassland and forest (Miller et al. 2016). Later investigations of how modern forest and grasslands are represented in the pollen rain (Julier et al. 2019) suggest that this magnitude of change could, for a large part, be explained by variation in the woody component of grassland ecosystems, rather than switching to a closed evergreen forest. Therefore, during the period from which the earliest archaic $H$. sapiens fossils have been found at Jebel Irhoud the landscape around Lake Bosumtwi was most likely covered with a wooded savannah.

We find that during the period 400-250 ka (MIS 11.2-8.2) the sites representative of northern and western Africa show a dynamic vegetation cover, but likely were not inhospitable to hominins. 
The eastern African record was likely arid for much of this period which could have created a geographic barrier to hominins.

\subsubsection{Vegetational trends throughout Africa between 250-100 ka (MIS 8.2-5.3)}

Between 250 and $100 \mathrm{ka}$ past vegetation data is available from the Padul Basin (PB; Torres et al. 2020) in northern Africa, Lake Magadi (MAG14; Owen et al. 2018) and Lake Malawi (MAL05-1B/1C; Ivory et al. 2018) in eastern Africa, and Lake Bosumtwi (BOS04-5B; Miller and Gosling 2014) in western Africa records plus, for the younger final few thousand years, parts of the Vankervelsvlei (VVV10.1; Quick et al. 2016) southern Africa, and Lake Malawi (1C; Beuning et al. 2011) eastern Africa records. In this time window, we expect a dominance of an open vegetation structure that promoted the dispersal, and consequently gene flow, between morphologically dissimilar archaic $H$. sapiens populations. This increased connectiveness would have ultimately lead to the full range of AMH associated phenotypical characteristics throughout the entire $H$. sapiens clade.

There is evidence for forest development at PB during the 250-100 ka interval (MIS 8.0-6.5) as indicated by the high abundance of evergreen taxa (Pinus $>50 \%$ through most of this period) and deciduous taxa in parts (e.g. Quercus, c. 10\%, 270-250 ka), indicating relatively stable vegetation structure with a strong woody component. The forest vegetation could have been less favourable to $H$. sapiens encouraging populations to move to find more open environment to which they were more familiar.

The high diversity of pollen taxa present in record MAG14 between 250-100 ka suggests that many different ecosystems were present along the banks of Lake Magadi. Within this time window Afromontane taxa diminishing in favour of the relatively open Zambezian Miombo woodland and humid evergreen woodlands, offering a diverse landscape vegetation mosaic with a wide variety in resources and thereby generating hospitable environments for archaic $H$. sapiens. The other lake core from eaststern Africa considered here, Lake Malawi, shows high variation in landscape openness. Five wooded grassland periods with a combined duration of $c .90 \mathrm{ka}$ have been identified at Lake Malawi, giving ample oppurtunities for archaic $H$. sapiens to settle and disperse through the vicinity of Lake Malawi. Thus, both eastern African records indicate vegetation that would have been hospitable to archaic $H$. sapiens, and could have provided a north-south corridor allowing connectivity across the continent.

The pollen record from Lake Bosumtwi suggests an expanded savannah in western Africa, unprecedented in both stability (lasting almost $100 \mathrm{kyr}$ ) and cover (reaching $>95 \%$ Poaceae). The consequences of this heavily grass-dominated landscape for $H$. sapiens could be interpreted in two ways: (i) as an ideal open landscape which they could occupy and traverse comfortably, or (ii) as a barrier due to high aridity and a lack of resources (absence of trees and water). The absence of any archaeological evidence of $H$. sapiens in western Africa until c. 12 ka (Harvati et al. 2011) tentatively provides support for the latter, but further evidence is clearly required.

The Vankervelsvlei sedimentary record begins $c .110 \mathrm{ka}$ and contains pollen indicative of predominantly open woodland vegetation. This relatively open woodland could have provided a favourable to $H$. sapiens in a similar way to the vegetation of eastern Africa.

During the period 250-100 ka we find that there are potential barriers to H. sapiens in the north (covered by forest) and western (arid ecosystems) regions of Africa. While in the eastern and southern regions there is evidence for more hospitable vegetation configurations.

\subsubsection{Vegetational trends throughout Africa after $100 \mathrm{ka}$ (MIS 5.3)}

The last $100 \mathrm{ka}$ is an important period in hominin evolution and dispersal, particularly related to the movement of hominins out-of-Africa between 70 and $40 \mathrm{ka}$ (MIS 5.0-3.2; (Blome et al. 2012; Carto et al. 2009; Tierney et al. 2017)). During this period an increasing amount of 
information on past vegetation change in Africa is available, however, a detailed exploration of all this literature is beyond the scope of this review. Instead, we limit this section to briefly contextualizing change around the period of movement of hominins out-of-Africa from just the six records used to provide information on longer-term vegetation change (Figure 4C).

The northern African vegetational makeup, as inferred from the PB pollen record, implies steppic environmental conditions with high Artemisia and Poaceae presence in the Mediterranean regions of northwest Africa for MIS 4 and MIS 3, indicating cold and arid climate for both stages (Torres et al. 2020). While in southern Africa the VVV10.1 pollen record suggests vegetation remain fairly stable in their characteristics over the last $100 \mathrm{ka}$, notwithstanding an expansion of fynbos vegetation between 70-40 ka (Quick et al. 2016). Similar vegetation stability is also seen in eastern Africa from the MAG14 pollen record (Owen et al. 2018), although the MAL 1C pollen record shows a trajectory of increasing woodland vegetation (Beuning et al. 2011). This increase in woodland vegetation has been interpreted as increased landscape diversity that could have aided hominin development and dispersal by providing access to new and more varied resources (Beuning et al. 2011). In central (record B12) and western Africa (record BOS04-5B) the degree of vegetation openness is shown to fluctuate; with the greatest depression of the treeline (hence most open vegetation being available at high elevation) occurring at Lake Bambili around $35 \mathrm{ka}$ (Lézine et al. 2019).

Through the period of hominin dispersal 'Out-of-Africa', some portion of each of the six records indicates open vegetation that would have helped to facilitate dispersal of hominins. It is also the period in which the greatest variation in the vegetation record is seen, which could also have promoted dispersal as hominins sought to track resources. However, we should be cautious in our interpretations because the evidence is likely biased by the increased number of locations from which evidence is available, and the temporal detail of the information.

\subsection{CONCLUSIONS}

Growing evidence from genetic and archaeological sources paints a picture of complex panAfrican hominin evolution, development and dispersal (Hublin et al. 2017; Lipson et al. 2020; Scerri et al. 2018; Stringer 2016; Wang et al. 2020). Intuitively it seems reasonable that the habitat that hominins existed within played an important role in shaping these processes and, based on archaeological evidence, it has been suggested that more open vegetation formations were the favoured habitat of early hominins (Bertola et al. 2016; Blome et al. 2012; Cerling et al. 2011; Larrasoaña et al. 2013; Scerri et al. 2018). However, unfortunately, evidence for vegetation, and vegetation change, over the more than half-million years over which evolution, development and dispersal have occurred remains scant at the continental scale. The terrestrial records of past vegetation change, based on the analysis of ancient pollen, obtained from six sedimentary basins that are relevant to Africa on these timescales indicate that the degree of openness varied regionally. The balance between a predominance of open $v s$. closed vegetation across Africa tends to follow a pattern of indicating more hospitable (open vegetation) during the period 500-400 ka when archaic $H$. sapiens dispersed around the continent, more inhospitable (closed vegetation/desert) between 400-250 ka when many new phenotypically distinct clades of hominins arose, and a return to more hospitable (open vegetation) conditions 250-100 ka coincident with the rise of anatomically modern humans. This pattern of vegetation change fits with our proposed 'Inside-of-Africa' environmental framework as a backdrop to hominin evolution. While these data provide some evidence for vegetation change in Africa over the last $500 \mathrm{ka}$ there are clearly huge spatial and temporal gaps in the evidence available. Consequently, any inferences drawn from this must be done so with caution, however, we hope that our proposed framework will provide food for thought among researchers and be subsequently tested against new and more detailed records of past vegetation change. 


\section{ACKNOWLEDGEMENTS}

We would like to thank all the authors of the original publications which we review here for publishing their studies and making their data available either through open access databases or directly following corresponance. We thank Alayne Street-Perrott (Swansea University, UK) and Anne-Marie Lézine (CNRS, France) for their thorough evaluation and feedback on our manuscript, and the PoA editorial team for the opportunity to contribute to this volume.

\section{REFERENCES}

Bailey, R.C., Head, G., Jenike, M., Owen, B., Rechtman, R. and Zechenter, E., 1989, Hunting and Gathering in Tropical Rain Forest: Is It Possible? American Anthropologist, 91(1), pp. 59-82, 10.1525/aa.1989.91.1.02a00040.

Behrensmeyer, A.K., Potts, R., Deino, A.L. and Ditchfield, P., 2002, Olorgesailie, Kenya: a Million Years in the Life of a Rift Basin. Sedimentation in Continental Rifts, pp. 97-106.

Bertola, L.D., Jongbloed, H., Van Der Gaag, K.J., De Knijff, P., Yamaguchi, N., Hooghiemstra, H., Bauer, H., Henschel, P., White, P.A., Driscoll, C.A., Tende, T., Ottosson, U., Saidu, Y., Vrieling, K. and De Iongh, H.H., 2016, Phylogeographic Patterns in Africa and High Resolution Delineation of Genetic Clades in the Lion (Panthera leo). Scientific Reports, 6, article: 30807, 10.1038/ srep30807.

Beuning, K.R.M., Zimmerman, K.A., Ivory, S.J. and Cohen, A.S., 2011, Vegetation response to glacial-interglacial climate variability near Lake Malawi in the southern African tropics. Palaeogeography, Palaeoclimatology, Palaeoecology, 303(1-4), pp. 81-92, 10.1016/j.palaeo.2010.01.025.

Blome, M.W., Cohen, A.S., Tryon, C.A., Brooks, A.S. and Russell, J., 2012, The environmental context for the origins of modern human diversity: A synthesis of regional variability in African climate 150,000-30,000 years ago. Journal of Human Evolution, 62(5), pp. 563-592, 10.1016/j.jhevol.2012.01.011.

Brooks, A.S., Yellen, J.E., Potts, R., Behrensmeyer, A.K., Deino, A.L., Leslie, D.E., Ambrose, S.H., Ferguson, J.R., D’Errico, F., Zipkin, A.M., Whittaker, S., Post, J., Veatch, E.G., Foecke, K. and Clark, J.B., 2018, Long-distance stone transport and pigment use in the earliest Middle Stone Age. Science, 360(6384), pp. 90-94, 10.1126/science.aao2646.

Campisano, C.J., Cohen, A.S., Arrowsmith, J.R., Asrat, A., Behrensmeyer, A.K., Brown, E.T., Deino, A.L., Deocampo, D.M., Feibel, C.S., Kingston, J.D., Lamb, H.F., Lowenstein, T.K., Noren, A., Olago, D.O., Owen, R.B., Pelletier, J.D. and Potts, R., 2017, The Hominin Sites and Paleolakes Drilling Project: High resolution paleoclimate records from the East African Rift System and their implications for understanding the environmental context of hominin evolution. PaleoAnthropology, pp. 1-43.

Carto, S.L., Weaver, A.J., Hetherington, R., Lam, Y. and Wiebe, E.C., 2009, Out of Africa and into an ice age: on the role of global climate change in the Late Pleistocene migration of early modern humans out of Africa. Journal of Human Evolution, 56(2), pp. 139-151, 10.1016/j.jhevol.2008.09.004.

Castañeda, I.S., Caley, T., Dupont, L., Kim, J.H., Malaizé, B. and Schouten, S., 2016, Middle to Late Pleistocene vegetation and climate change in subtropical southern East Africa. Earth and Planetary Science Letters, 450, pp. 306-316, 10.1016/j.eps1.2016.06.049.

Cerling, T.E., Wynn, J.G., Andanje, S.A., Bird, M.I., Korir, D.K., Levin, N.E., MacE, W., MacHaria, A.N., Quade, J. and Remien, C.H., 2011, Woody cover and hominin environments in the past 6-million years. Nature, 476(7358), pp. 51-56, 10.1038/nature10306.

Chan, E.K.F., Timmermann, A., Baldi, B.F., Moore, A.E., Lyons, R.J., Lee, S.S., Kalsbeek, A.M.F., Petersen, D.C., Rautenbach, H., Förtsch, H.E.A., Bornman, M.S.R. and Hayes, V.M., 
2019, Human origins in a southern African palaeo-wetland and first migrations. Nature, 575(7781), pp. 185-189, 10.1038/s41586-019-1714-1.

Chen, D. and Chen, H.W., 2013, Using the Köppen classification to quantify climate variation and change: An example for 1901-2010. Environmental Development, 6(1), pp. 69-79, 10.1016/j.envdev.2013.03.007.

Clement, A.C., Hall, A. and Broccoli, A.J., 2004, The importance of precessional signals in the tropical climate. Climate Dynamics, 22(4), pp. 327-341, 10.1007/s00382-003-0375-8.

Compton, J.S., 2011, Pleistocene sea-level fluctuations and human evolution on the southern coastal plain of South Africa. Quaternary Science Reviews, 30(5-6), pp. 506-527, 10.1016/j.quascirev.2010.12.012.

Coulthard, T.J., Ramirez, J.A., Barton, N., Rogerson, M. and Brücher, T., 2013, Were rivers flowing across the Sahara during the last interglacial? Implications for human migration through Africa. PloS One, 8(9), article: e74834, 10.1371/journal.pone.0074834.

D’Errico, F., Banks, W.E., Warren, D.L., Sgubin, G., Van Niekerk, K., Henshilwood, C., Daniau, A.L. and Sánchez Goñi, M.F., 2017, Identifying early modern human ecological niche expansions and associated cultural dynamics in the South African Middle Stone Age. Proceedings of the National Academy of Sciences, 114(30), pp. 7869-7876, 10.1073/pnas.1620752114.

Dalibard, M., Popescu, S.M., Maley, J., Baudin, F., Melinte-Dobrinescu, M.C., Pittet, B., Marsset, T., Dennielou, B., Droz, L. and Suc, J.P., 2014, High-resolution vegetation history of West Africa during the last 145 ka. Geobios, 47(4), pp. 183-198, 10.1016/j.geobios.2014.06. 002 .

Deino, A.L., Behrensmeyer, A.K., Brooks, A.S., Yellen, J.E., Sharp, W.D. and Potts, R., 2018, Chronology of the Acheulean to Middle Stone Age transition in eastern Africa. Science, 360, pp. 95-98, 10.1126/science.aao2216.

Douze, K., Wurz, S. and Henshilwood, C.S., 2015, Techno-cultural characterization of the MIS $5($ c. $105-90 \mathrm{Ka})$ lithic industries at Blombos Cave, Southern Cape, South Africa. PLoS ONE, 10(11), pp. 1-29, 10.1371/journal.pone.0142151.

Dupont, L.M., 1989, Palynology of the last 680000 years of ODP Site 658 (off NW Africa): fluctuations in paleowind systems. In: Paleoclimatology and Paleometeorology: Modern and past patterns of global atmospheric transport edited by Leinen, M. and Sarnthein, M., pp. 719 794, (Dordrecht: Kluwer).

Dupont, L., 2011, Orbital scale vegetation change in Africa. Quaternary Science Reviews, 30(25-26), pp. 3589-3602, 10.1016/j.quascirev.2011.09.019.

Dupont, L. M. and Hooghiemstra, H., 1989, The Saharan-Sahelian boundary during the Brunhes chron. Acta Botanica Neerlandica, 38(4), pp. 405-415, 10.1111/j.1438-8677.1989.tb01372.x.

Dupont, Lydie M., Jahns, S., Marret, F. and Ning, S., 2000, Vegetation change in equatorial West Africa: Time-slices for the last $150 \mathrm{ka}$. Palaeogeography, Palaeoclimatology, Palaeoecology, 155(1-2), pp. 95-122, 10.1016/S0031-0182(99)00095-4.

Endicott, P., Ho, S.Y.W. and Stringer, C., 2010, Using genetic evidence to evaluate four palaeoanthropological hypotheses for the timing of Neanderthal and modern human origins. Journal of Human Evolution, 59(1), pp. 87-95, 10.1016/j.jhevol.2010.04.005.

Frédoux, A., 1994, Pollen analysis of a deep-sea core in the Gulf of Guinea: vegetation and climatic changes during the last 225,000 years B.P. Palaeogeography, Palaeoclimatology, Palaeoecology, 109(2-4), pp. 317-330, 10.1016/0031-0182(94)90182-1.

Frumkin, A., Bar-Yosef, O. and Schwarcz, H.P., 2011, Possible paleohydrologic and paleoclimatic effects on hominin migration and occupation of the Levantine Middle Paleolithic. Journal of Human Evolution, 60(4), pp. 437-451, 10.1016/j.jhevol.2010.03.010.

Galway-Witham, J., Cole, J. and Stringer, C., 2019, Aspects of human physical and behavioural evolution during the last 1 million years. Journal of Quaternary Science, 34(6), pp. 355-378, $10.1002 /$ jqs. 3137. 
Gosling, W.D. and Holden, P.B., 2011, Precessional forcing of tropical vegetation carbon storage. Journal of Quaternary Science, 26(5), pp. 463-467, 10.1002/jqs.1514.

Grun, R., Brink, J.S., Spooner, N.A., Taylor, L., Stringer, C.B., Franciscus, R.G. and Murray, A.S., 1996, Direct dating of Florisbad hominid. Nature, 382(6591), pp. 500-501, 10.1038/382500a0

Gunz, P., Bookstein, F.L., Mittero, P., Stadlmayr, A., Seidler, H., Gerhard, W., Weber, G.W., Kelly, D.J., Poolman, B., Gavin, H., Zeniou-meyer, M., Liu, Y., Olanich, M.E., Becherer, U., Bader, M. and Vitale, N., 2009, Early modern human diversity suggests subdivided population structure and a complex out-of-Africa scenario. Proceedings of the National Academy of Sciences, 106(20), pp. 8398-8398, 10.1073/pnas.0903734106.

Hammond, A.S., Royer, D.F. and Fleagle, J.G., 2017, The Omo-Kibish I pelvis. Journal of Human Evolution, 108, pp. 199-219, 10.1016/j.jhevol.2017.04.004.

Harvati, K., Stringer, C., Grün, R., Aubert, M., Allsworth-Jones, P. and Folorunso, C.A., 2011, The later stone age calvaria from Iwo Eleru, Nigeria: Morphology and chronology. PLoS ONE, 6(9), pp. 1-8, 10.1371/journal.pone.0024024.

Henshilwood, C.S., D’Errico, F., Van Niekerk, K.L., Coquinot, Y., Jacobs, Z., Lauritzen, S.E., Menu, M. and García-Moreno, R., 2011, A 100,000-year-old ochre-processing workshop at Blombos Cave, South Africa. Science, 334(6053), pp. 219-222, 10.1126/science.1211535.

Hooghiemstra, H., Stalling, H., Agwu, C. and Dupont, L.M., 1992, Vegetational and climatic changes at the northern fringe of the Sahara 250,000-5,000 years BP. Review of Palaeobotany and Palynology, 74, pp. 1-53, 10.1016/0034-6667(92)90137-6.

Hooghiemstra, H., Agwu, C.O.C. and Beug, H.-J., 1986, Pollen and spore distribution in recent marine sediments: a record of NW-African seasonal wind patterns and vegetation belts. Meteor Forschungsergebnisse, Reihe C Geologie Und Geophysik, 40(40), pp. 87-135.

Hooghiemstra, H., Lézine, A.M., Leroy, S.A.G., Dupont, L. and Marret, F., 2006, Late Quaternary palynology in marine sediments: A synthesis of the understanding of pollen distribution patterns in the NW African setting. Quaternary International, 148(1), pp. 29-44, 10.1016/j.quaint.2005.11.005.

Hublin, J.J., Ben-Ncer, A., Bailey, S.E., Freidline, S.E., Neubauer, S., Skinner, M.M., Bergmann, I., Le Cabec, A., Benazzi, S., Harvati, K. and Gunz, P., 2017, New fossils from Jebel Irhoud, Morocco and the pan-African origin of Homo sapiens. Nature, 546(7657), pp. 289-292, 10.1038 /nature22336.

Imbrie, J., Hays, J.D., Martinson, D.G., Mclntyre, A., Mix, A.C., Morley, J.J., Pisias, N.G., Prell, W.L. and Shackleton, N.J., 1984, The orbital theory of Pleistocene climate: support from a revised chronology of the marine $\delta^{18} \mathrm{O}$ record. In: Milankovitch and Climate edited by Berger, A., Imbrie, J., Hays, G., Kukla, G. and Saltzman, B., pp. 269-306, (Dordrecht: Reidel).

Ivory, S.J., Blome, M.W., King, J.W., McGlue, M.M., Cole, J.E. and Cohen, A.S., 2016, Environmental change explains cichlid adaptive radiation at Lake Malawi over the past 1.2 million years. Proceedings of the National Academy of Sciences, 113(42), pp. 11895-11900, 10.1073/pnas.1611028113.

Ivory, S.J., Lézine, A.-M., Vincens, A. and Cohen, A.S., 2018, Waxing and waning of forests: Late Quaternary biogeography of southeast Africa. Global Change Biology, 24(7), pp. 2939-2951, 10.1111/gcb.14150.

Jacobs, Z., Duller, G.A.T., Wintle, A.G. and Henshilwood, C.S., 2006, Extending the chronology of deposits at Blombos Cave, South Africa, back to $140 \mathrm{ka}$ using optical dating of single and multiple grains of quartz. Journal of Human Evolution, 51(3), pp. 255-273, 10.1016/j.jhevol.2006.03.007.

Jacobs, Z., Roberts, R.G., Galbraith, R.F., Deacon, H.J., Grün, R., Mackay, A., Mitchell, P., Vogelsang, R. and Wadley, L., 2008, Ages for the Middle Stone Age of southern Africa: Implications for human behavior and dispersal. Science, 322(5902), pp. 733-735, $10.1126 /$ science. 1162219 .

Jacobson, G.L. and Bradshaw, R.H.W., 1981, The selection of sites for paleovegetational studies. Quaternary Research, 96, pp. 80-96, 10.1016/0033-5894(81)90129-0. 
Jahns, S., Hüls, M. and Sarnthein, M., 1998, Vegetation and climate history of west equatorial Africa based on a marine pollen record off Liberia (site GIK 16776) covering the last 400,000 years. Review of Palaeobotany and Palynology, 102(3-4), pp. 277-288, 10.1016/S00346667(98)80010-9.

Jourdan, F., Renne, P.R. and Reimold, W.U., 2009, An appraisal of the ages of terrestrial impact structures. Earth and Planetary Science Letters, 286(1-2), pp. 1-13, 10.1016/j.epsl. 2009.07.009.

Julier, A.C.M., Jardine, P.E., Adu-Bredu, S., Coe, A.L., Fraser, W.T., Lomax, B.H., Malhi, Y., Moore, S. and Gosling, W.D., 2019, Variability in modern pollen rain from moist and wet tropical forest plots in Ghana, West Africa. Grana, 58(1), pp. 45-62, 10.1080/00173134.2018.1510027.

Koeberl, C., Milkereit, B., Overpeck, J.T., Scholz, C.A., Amoako, P.Y.O., Boamah, D., Danuor, S.K., Karp, T., Kueck, J., Hecky, R.E., King, J.W. and Peack, J.A., 2007, An international and multidisciplinary drilling project into a young complex impact structure: The 2004 ICDP Bosumtwi Crater Drilling Project - An overview. Meteoritics and Planetary Science, 42(4-5), pp. 483-511, 10.1111/j.1945-5100.2007.tb01057.x.

Lamb, H.F., Bates, C.R., Bryant, C.L., Davies, S.J., Huws, D.G., Marshall, M.H. and Roberts, H.M., 2018, 150,000-year palaeoclimate record from northern Ethiopia supports early, multiple dispersals of modern humans from Africa. Scientific Reports, 8(1), article: 1077, 10.1038/s41598-018-19601-w.

Larrasoaña, J.C., Roberts, A.P. and Rohling, E.J., 2013, Dynamics of green Sahara periods and their role in hominin evolution. PLoS ONE, 8(10), e 76514, 10.1371/journal.pone.0076514.

Lavachery, P., 2001, The holocene archaeological sequence of Shum Laka rock shelter (Grassfields, western Cameroon). African Archaeological Review, 18(4), pp. 213-247, 10.1023/ A:1013114008855.

Lézine, A.-M., Holl, A.F.C., Lebamba, J., Vincens, A., Assi-Khaudjis, C., Février, L. and Sultan, É., 2013, Temporal relationship between Holocene human occupation and vegetation change along the northwestern margin of the Central African rainforest. Comptes Rendus-Geoscience, 345(7-8), pp. 327-335, 10.1016/j.crte.2013.03.001.

Lézine, A.M., Izumi, K., Kageyama, M. and Achoundong, G., 2019, A 90,000-year record of Afromontane forest responses to climate change. Science, 363(6423), pp. 177-181, $10.1126 /$ science.aav6821.

Lieberman, D.E., McBratney, B.M. and Krovitz, G., 2002, The evolution and development of cranial form in Homo sapiens. Proceedings of the National Academy of Sciences, 99(3), pp. 1134-1139, 10.1073/pnas.022440799.

Lipson, M., Ribot, I., Mallick, S., Rohland, N., Olalde, I., Adamski, N., Broomandkhoshbacht, N., Lawson, A.M., López, S., Oppenheimer, J., Stewardson, K., Asombang, R.N., Bocherens, H., Bradman, N., Culleton, B.J., Cornelissen, E., Crevecoeur, I., de Maret, P., Fomine, F.L.M., and Reich, D., 2020, Ancient West African foragers in the context of African population history. Nature, 577(7792), pp. 665-670, 10.1038/s41586-020-1929-1.

Lisiecki, L.E. and Raymo, M.E., 2005, A Pliocene-Pleistocene stack of 57 globally distributed benthic $\delta 180$ records. Paleoceanography, 20(1), pp. 1-17, 10.1029/2004PA001071.

McDougall, I., Brown, F.H. and Fleagle, J.G., 2005, Stratigraphic placement and age of modern humans from Kibish, Ethiopia. Nature, 433(7027), pp. 733-736, 10.1038/ nature 03258 .

Miller, C.S. and Gosling, W.D., 2014, Quaternary forest associations in lowland tropical West Africa. Quaternary Science Reviews, 84, pp. 7-25, 10.1016/j.quascirev.2013. 10.027 .

Miller, C.S., Gosling, W.D., Kemp, D.B., Coe, A.L. and Gilmour, I., 2016, Drivers of ecosystem and climate change in tropical West Africa over the past $\sim 540000$ years. Journal of Quaternary Science, 31(7), pp. 671-677, 10.1002/jqs.2893. 
Mirazón Lahr, M. and Foley, R.A., 2016, Human Evolution in Late Quaternary Eastern Africa. In: Africa from MIS 6-2: Population Dynamics and Paleoenvironments edited by Jones, S. and Stewart, B., pp. 215-231, (Dordrecht: Springer).

Mounier, A. and Mirazón Lahr, M., 2016, Virtual ancestor reconstruction: Revealing the ancestor of modern humans and Neandertals. Journal of Human Evolution, 91, pp. 57-72, 10.1016/j.jhevol.2015.11.002.

Neubauer, S., Hublin, J.J. and Gunz, P., 2018, The evolution of modern human brain shape. Science Advances, 4(1), article: eaao5961, 10.1126/sciadv.aao5961.

Olson, D.M., Dinerstein, E., Wikramanayake, E.D., Burgess, N.D., Powell, G.V.N., Underwood, E.C., D'amico, J.A., Itoua, I., Strand, H.E., Morrison, J.C., Loucks, C.J., Allnutt, T.F., Ricketts, T.H., Kura, Y., Lamoreux, J.F., Wettengel, W.W., Hedao, P. and Kassem, K.R., 2001, Terrestrial Ecoregions of the World: A New Map of Life on Earth: A new global map of terrestrial ecoregions provides an innovative tool for conserving biodiversity. Bioscience, 51(11), pp. 933-938, 10.1641/0006-3568(2001)051[0933:TEOTWA]2.0.CO;2.

Osborne, A.H., Vance, D., Rohling, E.J., Barton, N., Rogerson, M. and Fello, N., 2008, A humid corridor across the Sahara for the migration of early modern humans out of Africa 120,000 years ago. Proceedings of the National Academy of Sciences, 105(43), pp. 16444-16447, 10.1073/pnas.0804472105.

Owen, R.B., Muiruri, V.M., Lowenstein, T.K., Renaut, R.W., Rabideaux, N., Luo, S., Deino, A.L., Sier, M.J., Dupont-Nivet, G., Mcnulty, E.P., Leet, K., Cohen, A., Campisano, C., Deocampo, D., Shen, C.C., Billingsley, A. and Mbuthia, A., 2018, Progressive aridification in East Africa over the last half million years and implications for human evolution. Proceedings of the National Academy of Sciences, 115(44), pp. 11174-11179, 10.1073/pnas.1801357115.

Ozenda, P., 1991, Flore et Végétation du Sahara. (Paris: Centre Nationale Recherche Scientifique).

Pearson, O.M., 2008, Statistical and biological definitions of anatomically modern humans: Suggestions for a unified approach to modern morphology. Evolutionary Anthropology, 17(1), pp. 38-48, 10.1002/evan.20155.

Quade, J., Dente, E., Armon, M., Ben Dor, Y., Morin, E., Adam, O. and Enzel, Y., 2018, Megalakes in the Sahara? A Review. Quaternary Research, 90(2), pp. 253-275, 10.1017/qua.2018.46.

Quick, L.J., Meadows, M.E., Bateman, M.D., Kirsten, K.L., Mäusbacher, R., Haberzettl, T. and Chase, B.M., 2016, Vegetation and climate dynamics during the last glacial period in the fynbos-afrotemperate forest ecotone, southern Cape, South Africa. Quaternary International, 404, pp. 136-149, 10.1016/j.quaint.2015.08.027.

Richter, D., Grün, R., Joannes-Boyau, R., Steele, T.E., Amani, F., Rué, M., Fernandes, P., Raynal, J.P., Geraads, D., Ben-Ncer, A., Hublin, J.J. and McPherron, S.P., 2017, The age of the hominin fossils from Jebel Irhoud, Morocco, and the origins of the Middle Stone Age. Nature, 546(7657), pp. 293-296, 10.1038/nature22335.

Rivas-Martínez, S., 1987, Memoria del mapa de Series de Vegetación de España, 1:400.000, (Madrid: Ministerio de Agricultura, Pesca y Alimentación, ICONA).

Roets, W., Xu, Y., Raitt, L., El-Kahloun, M., Meire, P., Calitz, F., Batelaan, O., Anibas, C., Paridaens, K., Vandenbroucke, T., Verhoest, N.E.C. and Brendonck, L., 2008, Determining discharges from the Table Mountain Group (TMG) aquifer to wetlands in the Southern Cape, South Africa. Hydrobiologia, 607(1), pp. 175-186, 10.1007/s10750-008-9389-x.

Rubel, F. and Kottek, M., 2010, Observed and projected climate shifts 1901-2100 depicted by world maps of the Köppen-Geiger climate classification. Meteorologische Zeitschrift, 19(2), pp. 135-141, 10.1127/0941-2948/2010/0430.

Scerri, E.M.L., 2017a, The West African Stone Age. Oxford Research Encyclopedia of African History, 10.1093/acrefore/9780190277734.013.137.

Scerri, E.M.L., 2017b, The North African Middle Stone Age and its place in recent human evolution. Evolutionary Anthropology, 26(3), pp. 119-135, 10.1002/evan.21527. 
Scerri, E.M.L., Thomas, M.G., Manica, A., Gunz, P., Stock, J.T., Stringer, C., Grove, M., Groucutt, H.S., Timmermann, A., Rightmire, G.P., d'Errico, F., Tryon, C.A., Drake, N.A., Brooks, A.S., Dennell, R.W., Durbin, R., Henn, B.M., Lee-Thorp, J., deMenocal, P., Petraglia, M.D., Thompson, J.C., Scally, A. and Chikhi, L., 2018, Did Our Species Evolve in Subdivided Populations across Africa, and Why Does It Matter? Trends in Ecology and Evolution, 33(8), pp. 582-594, 10.1016/j.tree.2018.05.005.

Schlebusch, C., Loog, L., Groucutt, H., King, T., Rutherford, A., Barbieri, C., Barbujani, G., Chikhi, L., Stringer, C., Jakobsson, M., Eriksson, A., Manica, A., Tishkoff, S.A., Scerri, E.M.L., Scally, A., Brierley, C. and Thomas, M.G., 2021, Human origins in Southern African palaeo-wetlands? Strong claims from weak evidence. Journal of Archaeological Science 130, article: $105374,10.1016 /$ j.jas.2021.105374.

Schlebusch, C.M., Malmström, H., Günther, T., Sjödin, P., Coutinho, A., Edlund, H., Munters, A.R., Vicente, M., Steyn, M., Soodyall, H., Lombard, M. and Jakobsson, M., 2017, Southern African ancient genomes estimate modern human divergence to 350,000 to 260,000 years ago. Science, 358(6363), pp. 652-655, 10.1126/science.aao6266.

Shanahan, T.M., Beck, J.W., Overpeck, J.T., McKay, N.P., Pigati, J.S., Peck, J.A., Scholz, C.A., Heil, C.W. and King, J., 2012, Late Quaternary sedimentological and climate changes at Lake Bosumtwi Ghana: New constraints from laminae analysis and radiocarbon age modeling. Palaeogeography, Palaeoclimatology, Palaeoecology, 361-362, pp. 49-60, 10.1016/j.palaeo.2012.08.001.

Shanahan, T.M., Peck, J.A., McKay, N., Heil, C.W., King, J., Forman, S.L., Hoffmann, D.L., Richards, D.A., Overpeck, J.T. and Scholz, C., 2013, Age models for long lacustrine sediment records using multiple dating approaches - An example from Lake Bosumtwi, Ghana. Quaternary Geochronology, 15, pp. 47-60, 10.1016/j.quageo.2012.12.001.

Stewart, J.R. and Stringer, C.B., 2012, Human evolution out of Africa: The role of refugia and climate change. Science, 335(6074), pp. 1317-1321, 10.1126/science.1215627.

Stringer, C., 2016, The origin and evolution of homo sapiens. Philosophical Transactions of the Royal Society B: Biological Sciences, 371(1698), article: 20150237, 10.1098/rstb.2015.0237.

Tiedeman, R., Sarnthein, M., Shackleton, N.J., 1994, Astronomic timescale for the Pliocene Atlantic 2180 and dust flux records of Ocean Drilling Program site 659. Paleoceanography, 9, pp. 619-638, 10.1029/94PA00208.

Tierney, J.E., deMenocal, P. and Zander, P.D., 2017, A climatic context for the out-of-Africa migration. Geology, 45(11), pp. 1023-1026, 10.1130/G39457.1.

Torres, T., Valle, M., Ortiz, J.E., Soler, V., Araujo, R., Rivas, M.R., Delgado, A., Julià, R. and Sánchez-Palencia, Y., 2020, 800 ka of Palaeoenvironmental changes in the Southwestern Mediterranean realm. Journal of Iberian Geology, 46(2), pp. 117-144, 10.1007/s41513-02000123-2.

Walter, R.C., Buffler, R.T., Bruggemann, J.H., Guillaume, M.M.M., Berhe, S.M., Negassi, B., Libsekal, Y., Cheng, H., Edwards, R.L., Von Cosel, R., Néraudeau, D. and Gagnon, M., 2000, Early human occupation of the Red Sea coast of Eritrea during the last interglacial. Nature, 405(6782), pp. 65-69, 10.1038/35011048.

Wang, K., Mathieson, I., O’Connell, J. and Schiffels, S., 2020, Tracking human population structure through time from whole genome sequences. PLoS Genetics, 16(3), article: e1008552, 10.1371/journal.pgen.1008552.

White, F., 1983, The Vegetation of Africa. (Paris: UNESCO).

White, T.D., Asfaw, B., Degusta, D., Gilbert, H., Richards, G.D., Suwa, G. and Howell, F.C., 2003, Pleistocene Homo sapiens from Middle Awash, Ethiopia. Nature, 423(6941), pp. 742-747, 10.1038/nature01669.

Zhao, M., Dupont, L., Eglinton, G. and Teece, M., 2003, n-Alkane and pollen reconstruction of terrestrial climate and vegetation for N.W. Africa over the last 160 kyr. Organic Geochemistry, 34(1), pp. 131-143, 10.1016/S0146-6380(02)00142-0. 